\title{
Mycotoxins, Pesticide Residues, and Heavy Metals Analysis of Croatian Cereals
}

\author{
Marija Kovač ${ }^{1}$, Mateja Bulaić ${ }^{1}$, Jasna Jakovljević ${ }^{1}$, Ante Nevistić ${ }^{1}$, Tomislav Rot ${ }^{1}$, Tihomir Kovač ${ }^{2,3, * * \text { (D, }}$ \\ Ivana Dodlek Šarkanj ${ }^{4}$ and Bojan Šarkanj ${ }^{4} \mathbb{B}$
}

1 Inspecto Ltd., Industrijska Zona Nemetin, Vukovarska Cesta 239b, 31000 Osijek, Croatia; marija.kovac@inspecto.hr (M.K.); mateja.bulaic@inspecto.hr (M.B.); jasna.jakovljevic@inspecto.hr (J.J.); ante.nevistic@inspecto.hr (A.N.); tomislav.rot@inspecto.hr (T.R.)

2 Faculty of Food Technology, Josip Juraj Strossmayer University of Osijek, Franje Kuhača 20, 31000 Osijek, Croatia

3 Department of Agrobiotechnology (IFA-Tulln), Institute of Bioanalytics and Agro-Metabolomics, University of Natural Resources and Life Sciences Vienna (BOKU), Konrad Lorenzstr. 20, 3430 Tulln, Austria

4 Department of Food Technology, University North, Trg dr. Žarka Dolinara 1, 48000 Koprivnica, Croatia; idsarkanj@unin.hr (I.D.Š.); bsarkanj@unin.hr (B.Š.)

* Correspondence: tihomir.kovac@ptfos.hr; Tel.: +385-31-224-341

Citation: Kovač, M.; Bulaić, M.; Jakovljević, J.; Nevistić, A.; Rot, T.; Kovač, T.; Dodlek Šarkanj, I.; Šarkanj, B. Mycotoxins, Pesticide Residues, and Heavy Metals Analysis of Croatian Cereals. Microorganisms 2021, 9, 216. https://doi.org/ 10.3390/microorganisms 9020216

Received: 5 December 2020

Accepted: 19 January 2021

Published: 21 January 2021

Publisher's Note: MDPI stays neutral with regard to jurisdictional claims in published maps and institutional affiliations.

Copyright: (c) 2021 by the authors. Licensee MDPI, Basel, Switzerland. This article is an open access article distributed under the terms and conditions of the Creative Commons Attribution (CC BY) license (https:/ / creativecommons.org/licenses/by/ $4.0 /)$.

\begin{abstract}
Cereals are still one of the most important food and feed sources, thus determining cereal's safety, i.e., compliance with legislation, is extremely important. As systematic investigations of nowadays unavoidable secondary fungal metabolites and other common legally regulated contaminants occurrence in Croatian cereals are still lacking, this research aims to monitor the contamination levels of nation-wide crops by mycotoxins, pesticide residues, and heavy metals by employing UHPLCMS/MS, GC-MS/MS, and atomic absorption spectrometer (AAS) validated analytical methods. The most common secondary fungal metabolites were found to be Fusarium mycotoxins, with DON being the most occurring present in $73.7 \%$ of the samples. At least one pesticide residue was found in $331.8 \%$ of the samples, and $\mathrm{Hg}$ and $\mathrm{Cd}$ were the most occurring heavy metals. A total of $8.5 \%$ of the samples was non-compliant to the European Union (EU) legislation for food regarding the found mycotoxins concentrations, $4.5 \%$ regarding pesticide residues and none regarding heavy metals. The unusual presence of certain pesticide residue and heavy metal indicates the importance of systematic control of the contaminant presence, in order to gather enough occurrence data for proper risk assessment that these contaminants represent for the consumer's health.
\end{abstract}

Keywords: mycotoxins; pesticide residues; heavy metals; occurrence data; food and feed safety

\section{Introduction}

The safety of cereals, and thus the quality, is of great importance since they represent one of the world's most important source of food and feed [1]. In Republic of Croatia, according to the Paying Agency for Agriculture, Fisheries and Rural Development, maize and wheat are the most represented agricultural crops, followed by barley, oats, rye, and triticale, which are usually less cultivated. Cereal safety can be compromised by various contaminants, entering any point of food chain, including production, storage, processing, and transport. Treatment of crops with plant protective agents may leave pesticides residues in products of plant origin and indirectly animal origin. Natural toxins, such as mycotoxins, may be biosynthesized in feed- and foodstuff, while heavy metals can be introduced through water, air, or soil, thus contaminating cereals and products thereof [2]. When assessing the risks associated with cereal consumption, mycotoxins, pesticide residues and heavy metals need to be regularly monitored from the field to end-use product and their interaction must be taken into account $[3,4]$. If further genetic traits of individuals are taken into account with all xenobiotics that it was exposed to, the exposome can be characterized [5-7]. 
Mycotoxins are secondary metabolites of low-amount toxicity produced by various toxigenic fungi species in a field and/or during storage, most important of them being Aspergillus, Fusarium, Alternaria, and Penicillium [8,9]. The most relevant mycotoxins for agricultural production worldwide are aflatoxins B1 (AFT B1), B2 (AFT B2), G1 (AFT G1), and G2 (AFT G2), deoxynivalenol (DON), fumonisins B1 (FB1) and B2 (FB2), zearalenone (ZEN), T-2 and HT-2 toxins, and ochratoxin A (OTA), regulated within the European Union (EU) via Commission Regulation (EC) No 1881/2006 [10](EC, 2006a), Commission Recommendation 2013/165/EU [11] (EC, 2013), Commission Recommendation 2006/576/EC [12] (EC, 2006b) and Directive 2002/32/EC [13] (EC, 2002a) in the terms of the highest permitted levels in certain foodstuff and feedstuff. The mycotoxin species and concentrations are found to be in a correlation with meteorological conditions in the year of crop harvest, thus some species prefer warm weather and moisture, while the other prefer hot and drought season [14-20].

Plant protective agents containing different active substances are frequently used in agriculture to protect plants from insects, pests and pathogens, as well as to improve the amount and quality of harvest [21]. As a result, it is possible that pesticide residues accumulate in both raw materials and food products, possessing various toxic effects on human and animal health [22,23]. Within the EU, pesticide residues levels in certain food and feed of plant and animal origin have been set by the Commission (EC) No 396/2005. The information regarding their maximum residue limit (MRL) and toxicity is also included in the EU Pesticide database of the European Commission [24].

Heavy metals contamination of crops arises from irrigation with contaminated water, the usage of fertilizers and metal-based plant protective agents, rapid industrialization and urbanization of agricultural regions [21,25]. Heavy metals, including lead $(\mathrm{Pb})$, cadmium $(\mathrm{Cd})$, arsenic (As), and mercury $(\mathrm{Hg})$, have no biological roles in a living organism and may induce numerous toxic effects, especially in children and embryos $[25,26]$. Accordingly, their concentrations in certain foodstuff and feedstuff are regulated within the EU via Commission Regulation (EC) No 1881/2006 [10] and Directive 2002/32/EC [13], setting the highest permitted levels in $\mathrm{mg} / \mathrm{kg}$.

Considering possible harmful effects of those contaminants groups, the usage of confirmatory analytical techniques such as liquid and gas chromatography (LC and GC) or inductively coupled plasma (ICP) coupled to (tandem) mass spectrometry (MS) in food safety control is crucial for unambiguous identification and quantification [27]. If such instruments are not available, the use of other instruments, as in our case the atomic absorption spectrometer (AAS) for the determination of metals, may be acceptable as long as they have satisfactory performance. However, mass spectrometry is preferred in a multicontaminant analysis of food and feed. Due to its selectivity, mass spectrometry requires no extensive clean-up steps and is particularly useful for simultaneous determination of multiple compounds which ensures fast, easy and inexpensive determination, and at the same time, analytical parameters that meet the quality criteria required by regulations [28].

The toxicological relevance of the above mentioned contaminants and residues is well established, however the total health impact of combined exposure to various mycotoxins, pesticide residues and heavy metals, which is nowadays unavoidable, is difficult to assess, and thus remains largely unknown [3,4,29]. Monitoring the incidence of these pollutants is crucial for proper health risk assessment, especially if considering the possibility of their combined (possibly synergistic) effect, as showed for the combination of mycotoxins, pesticides (chlorpyriphos, pyrimiphos-methyl) and heavy metals (Cd, As) [3]. As systematic investigations of their occurrence in Croatian cereals are still lacking, this research aims to monitor the multiple contamination levels of nation-wide crops by mycotoxins, pesticide residues and heavy metals. In addition, it is set to compare the found levels of contaminants to the tolerance values set by the EU legislation and determine compliance/non-compliance of the tested cereal samples. 


\section{Materials and Methods}

\subsection{Sample Collection}

Samples of cereals characteristic for the climate of the Republic of Croatia were selected to analyze and determine the occurrence of certain contaminants. A total of 118 cereal samples grown in the Croatian fields, including maize (61) and wheat (57), were collected from all Croatian counties, making sure that at least one sample originates from each county and the rest according to the representation, i.e., planting of agricultural areas with a certain cereal type. The sampling was carried out in warehouses/silos by trained manufacturer's personnel in accordance with the methods set out in Commission Regulation (EC) No 401/2006 [30]. Upon arrival at the laboratory, the samples were briefly stored (up to $48 \mathrm{~h}$ ) in a dry and dark place until milling to avoid subsequent production of mycotoxins as well as sample degradation in general. Samples were ground before analysis to obtain a homogeneous particle size (sieve pore size $0.5 \mathrm{~mm}$ ) using Romer RAS mill (Romer Labs, Austria). After milling, the samples were stored in a freezer at $-18{ }^{\circ} \mathrm{C}$ until analysis. All determination procedures applied for mycotoxins, pesticide residues and heavy metals analysis were previously successfully in-house validated and fitted to purpose.

\subsection{Chemicals, Reagents, and Standards}

Certified standards of mycotoxins were produced by Romer Labs Biopure (Romer Labs, Tulln, Austria), while certified pesticide and heavy metal standard solutions were obtained from CPAchem (CPAchem, Stara Zagora, Bulgaria). All standard solutions were stored according to manufacturer's instructions and tempered to room temperature before use. LC-MS and HPLC grade acetonitrile and methanol were produced by J.T. Baker (J.T. Baker, Deventer, The Netherlands). LC-MS grade formic acid, LC-MS ammonium formate, nitric acid $(65.0 \%)$ of trace analysis grade and hydrogen peroxide (30\%) of extra purity were produced by Sigma-Aldrich (Sigma-Aldrich, St. Louis, MO, USA). Ultrapure water was generated by Niro VV system (Nirosta d.o.o., Osijek, Croatia). A QuEChERS (Quick, Easy, Cheap, Effective, Rugged, and Safe) buffer-salt mixture was produced by Agilent (Agilent Technologies, Santa Clara, CA, USA) and each portion consisted of $1 \mathrm{~g}$ trisodium citrate dihydrate, $1 \mathrm{~g}$ sodium chloride, $0.5 \mathrm{~g}$ disodium hydrogen citrate sesquihydrate, and $4 \mathrm{~g}$ of anhydrous magnesium sulfate. dSPE salt mixture was obtained from the same producer and consisted of $900 \mathrm{mg}$ of anhydrous magnesium sulfate, $150 \mathrm{mg}$ of primary secondary amine, and $150 \mathrm{mg}$ graphitized carbon black.

\subsection{Mycotoxins Determination}

A dilute and shoot multimycotoxin LC-MS/MS method was used to determine 11 mycotoxins regulated in cereals by the above-mentioned EU legislative: AFB1, AFB2, AFG1, AFG2, DON, FB, FB2, ZEA, T-2, HT-2, and OTA. Sample preparation procedure used for analysis was adapted from Sulyok et al., (2020) [28]. Sample portion of $5 g$ was weighed into centrifuge tubes and extracted by solvent mixture 79/20/1 acetonitrile/ultrapure water/formic acid $(v / v / v)$ using mechanical shaker for $90 \mathrm{~min}$. Aliquot of the raw extract was afterwards diluted using 20/79/1 acetonitrile/ultrapure water/formic acid (v/v/v), filtered through $0.22 \mu \mathrm{m}$ nylon filter and without further clean-up injected into a LC-MS/MS system. Waters Acquity H-class UPLC system (Waters, Milford, MA, USA) was employed to perform chromatographic separation of selected mycotoxins by using a HSS T3 column $\left(100 \times 2.1 \mathrm{~mm}, 1.8 \mu \mathrm{m}\right.$ particle size) (Waters, Milford, MA, USA) maintained at $40{ }^{\circ} \mathrm{C}$. Gradient elution was carried out with eluent $\mathrm{A}$ consisting of an aqueous solution of ammonium formate $(5 \mathrm{mM})$ and eluent $B$ being methanol at constant flow rate of $0.3 \mathrm{~mL} / \mathrm{min}$. The volume of injected sample was $10 \mu \mathrm{L}$. The separation started with $95 \% \mathrm{~A}$ followed by linearly decrease to $50 \% \mathrm{~A}$ in $6 \mathrm{~min}$ and in the next $4 \mathrm{~min}$ to $5 \% \mathrm{~A}$ with a hold time of $5 \mathrm{~min}$, afterwards switching to $95 \% \mathrm{~A}$ and column equilibration to initial conditions in the next $3 \mathrm{~min}$. The UPLC system was coupled to Waters Xevo TQD tandem mass spectrometer (Waters, Milford, MA, USA) equipped with an electrospray ionization interface (ESI) oper- 
ating in both positive and negative ionization mode. ESI-MS/MS analysis was performed in multiple reaction monitoring (MRM) mode meaning that for each compound at least one precursor and two product ions were used for both identification and quantification purposes, selecting the most abundant product ion for quantification and the second one for confirmation purposes. Cone voltage and collision energy values were optimized for each precursor ion and different product ions. The ionization source parameters were: capillary voltage $1.5 \mathrm{kV}$, extractor voltage $3 \mathrm{~V}$, source temperature $150{ }^{\circ} \mathrm{C}$, desolvation temperature $400{ }^{\circ} \mathrm{C}$, cone gas flow $0 \mathrm{~L} / \mathrm{h}$, and desolvation gas flow $650 \mathrm{~L} / \mathrm{h}$ (both gases were nitrogen). Collision-induced dissociation was performed using argon as collision gas at a pressure of $4 \times 10^{-3} \mathrm{mbar}$ in the collision cell. Data acquisition was performed using MassLynx and TargetLynx software (v. 4.1., Waters, Milford, MA, USA). The MRM transitions for each mycotoxin and the applied cone voltages and collision energies are summarized in Table A1 in Appendix A.

Upon mycotoxin content determination and data analysis, the most relevant cereal samples containing very high or very low mycotoxin levels were selected (at least one from each county) and further subjected to pesticides and heavy metals analysis.

\subsection{Pesticide Residues Determination}

Standardized QuEChERS method (EN 15662) was employed in sample preparation procedure for pesticide residues (listed in Tables A2 and A3, Appendix A) determination. Samples (portions of $5 \mathrm{~g}$ ) were weighed into $50 \mathrm{~mL}$ centrifuge tubes and soaked in $10 \mathrm{~mL}$ of ultrapure water, followed by 1 min extraction using $10 \mathrm{~mL}$ of acetonitrile and $1 \mathrm{~min}$ extraction by addition of QuEChERS buffer-salt mixture. Sample tubes were then centrifuged for $5 \mathrm{~min}$ at $3000 \times \mathrm{g}$ at room temperature using Restek Q-sep 3000 centrifuge (Restek, Bellefonte, PA, USA). An aliquot of the organic phase $(6 \mathrm{~mL})$ from each sample was transferred into a $15 \mathrm{~mL}$ centrifuge tube containing dSPE salt mixture, shaken vigorously for $0.5 \mathrm{~min}$ and afterwards centrifuged at $3000 \times \mathrm{g}$ for $5 \mathrm{~min}$ at room temperature. The clean extract was filtered through $0.22 \mu \mathrm{m}$ nylon filter, transferred to a glass vial, and finally analyzed by LC-MS/MS and GC-MS/MS.

For LC-MS/MS determination, Xevo TQD tandem mass spectrometer (Waters, USA) equipped with ESI source and Acquity H-class UPLC system (Waters, USA) was used. For chromatographic separation Ultra Aqueous C18 column $(100 \times 2.1 \mathrm{~mm}, 3 \mu \mathrm{m}$ particle size) (Restek, USA) with a gradient elution consisting of eluent A (aqueous $4 \mathrm{mM}$ ammonium formate $/ 0.1 \%$ formic acid) and eluent B ( $4 \mathrm{mM}$ ammonium formate $/ 0.1 \%$ formic acid in methanol) was used. The analysis started with $90 \% \mathrm{~A}$, held for $1.5 \mathrm{~min}$, increased to $60 \% \mathrm{~B}$ in $2.5 \mathrm{~min}$ and in the next $4 \mathrm{~min}$ to $70 \% \mathrm{~B}$, and then to $100 \% \mathrm{~B}$ in $3 \mathrm{~min}$ with a $1 \mathrm{~min}$ hold, followed by $3 \mathrm{~min}$ return to initial conditions, to give a total run time of $15 \mathrm{~min}$. The flow rate was set to $0.5 \mathrm{~mL} / \mathrm{min}$ and the column temperature was maintained at $50^{\circ} \mathrm{C}$, while the injection volume was $10 \mu \mathrm{L}$. For analyte detection, MRM mode was applied and for each analyte at least two transitions were monitored (Table A2). The capillary voltage was $3.5 \mathrm{kV}$, the source temperature was $150^{\circ} \mathrm{C}$, and the desolvation gas temperature was $400{ }^{\circ} \mathrm{C}$. The desolvation gas flow was $650 \mathrm{~L} / \mathrm{h}$, while the cone gas flow was $10 \mathrm{~L} / \mathrm{h}$ (both nitrogen). Collision-induced dissociation was performed using argon as the collision gas at a pressure of $3.7 \times 10^{-3}$ mbar in the collision cell. The MassLynx and TargetLynx software (v. 4.1., Waters, USA) were used for the instrument control, data acquiring, and processing. GC-MS/MS used for pesticide determination was Trace 1300 gas chromatograph coupled to TSQ 8000 Evo tandem mass spectrometer (Thermo Scientific, Waltham, MA, USA) equipped with split/splitless injector operating in a splitless mode $(40 \mathrm{~mL} / \mathrm{min})$ at $200{ }^{\circ} \mathrm{C}$ with injection volume of $1 \mu \mathrm{L}$ and TG-XLBMS chromatographic column $(30 \mathrm{~m} \times 0.25 \mathrm{~mm} \times 0.25 \mu \mathrm{m})$ (Thermo Scientific, USA). The instrument control, data acquisition, and processing were conducted by TraceFinder software (v. 3.3, Thermo Scientific, Waltham, MA, USA). The gas carrier was helium (6.0) maintained at constant flow of $1.2 \mathrm{~mL} / \mathrm{min}$. Temperature program used for chromatographic separation was ranging from 40 to $300^{\circ} \mathrm{C}$ in four stages as follows: starts with $40{ }^{\circ} \mathrm{C}$ (hold time $1.5 \mathrm{~min}$ ), rises with rate of $25^{\circ} \mathrm{C} / \mathrm{min}$ to $90^{\circ} \mathrm{C}$ 
(1.5 min hold $)$ and then to $180{ }^{\circ} \mathrm{C}(0 \mathrm{~min}$ hold $), 5^{\circ} \mathrm{C} / \mathrm{min}$ to $280{ }^{\circ} \mathrm{C}(0 \mathrm{~min}$ hold $)$ and finally with $10{ }^{\circ} \mathrm{C} / \mathrm{min}$ to $300{ }^{\circ} \mathrm{C}$ (hold $10 \mathrm{~min}$ ). For ionization, electron impact ionization in positive mode was applied, with ion source temperature of $300{ }^{\circ} \mathrm{C}$ and MS transfer line temperature of $250{ }^{\circ} \mathrm{C}$. MRM mode was used for analyte detection, with the MS conditions optimized for each compound, as stated in Table A3.

\subsection{Heavy Metals Determination}

A Perkin Elmer AAnalyst 600 was used for determination of traces of heavy metals including $\mathrm{Pb}, \mathrm{Cd}, \mathrm{As}$, and $\mathrm{Hg}$. For the analysis of $\mathrm{Pb}, \mathrm{Cd}$, and $\mathrm{As}$, the graphite furnace performance was used, while for $\mathrm{Hg}$ analysis hydride technique was applied. Sample preparation procedure was based on sample degradation using microwave-assisted digestion and nitric acid $\left(\mathrm{HNO}_{3}\right)$ /hydrogen peroxide $\left(\mathrm{H}_{2} \mathrm{O}_{2}\right)$ as digestion reagents. Samples were accurately weighed by using plastic equipment to avoid cross-contamination (portion of $0.5 \mathrm{~g}$ ) into microwave tubes, $7 \mathrm{~mL}$ of $65 \% \mathrm{HNO}_{3}$, and $2 \mathrm{~mL}$ of $\mathrm{H}_{2} \mathrm{O}_{2}$ were added to each sample, followed by microwave digestion. Digestion program included 15 min heating procedure to $210^{\circ} \mathrm{C}$, holding at the achieved temperature for $20 \mathrm{~min}$ and cooling for the next $10 \mathrm{~min}$. Afterwards, samples were quantitatively transferred to volumetric flask by rinsing the tubes with ultrapure water. Aliquots $(1 \mu \mathrm{L})$ of prepared cereal samples were injected into the AAS. The instrument operating conditions for the determination of heavy metals were as follows: Pb-wavelength $283.3 \mathrm{~nm}$, slit width $0.7 \mathrm{~nm}$; Cd-wavelength $228.8 \mathrm{~nm}$, slit width $0.7 \mathrm{~nm}$; As-wavelength $193.7 \mathrm{~nm}$, slit width $0.7 \mathrm{~nm}$; Hg-wavelength $253.7 \mathrm{~nm}$, slit width $0.7 \mathrm{~nm}$.

\subsection{Method Validation}

Method validation for was carried according to the requirements of the accreditation standard ISO/IEC 17025 standard and relevant EU legislation [27,30-32].

Accuracy and precision for each method were estimated by means of recovery experiments at different spiking levels. Method procedures were applied to blank cereal samples spiked at three different concentration levels of each analyte and each sample was prepared in triplicate and injected in triplicate. Method accuracy was expressed as average recovery $(\mathrm{R} \%)$ and method precision (measurement repeatability) as relative standard deviation (RSD\%). The obtained results were satisfactory with most of the recoveries being between $70 \%$ and $120 \%$ and RSD below 20\%. Validation data on representative cereal (wheat), including achieved limits of detection (LOD) and quantification (LOQ) is shown in Tables A4-A6. Beside in-house validation, methods were also confirmed externally (measurement reproducibility) by successful participation in a proficiency testing schemes expressed by z-scores within range $|z| \leq \pm 2$ presented in Table A7 in Appendix B.

\section{Results and Discussion}

A total of 118 samples of Croatian cereals were collected from all twenty Croatian counties and analyzed for mycotoxins contamination levels, with the most significant samples regarding the mycotoxin content submitted to pesticides residues and heavy metals analyses. Previously in-house validated methods, fitted for purpose, were employed for all the contaminants determination procedures. The found compounds were quantified using external calibration (linear calibration polynomial type) in a solvent or appropriate matrix, with the measured concentrations corrected for method recovery analyzed within each batch if not within the range of $90-110 \%$ allowed for mycotoxins by Commission Regulation (EC) No 401/2006 [30], and within the range 70-120\% allowed for pesticide residues by SANTE/11813/2017 [31].

\subsection{Mycotoxins in Croatian Cereals}

The results of mycotoxin occurrence investigation are shown in the Table 1 . The most common mycotoxins found in all collected samples of different cultures at concentrations above LOD were Fusarium mycotoxins. The incidence of mycotoxins found in all analyzed 
samples was as follows: DON 73.7\% (63-4902 $\mu \mathrm{g} / \mathrm{kg})$, HT-2 45.8\% (3-41 $\mu \mathrm{g} / \mathrm{kg})$, FB1 $43.2 \%$ (61-9344 $\mu \mathrm{g} / \mathrm{kg})$, ZEA 36.4\% (10-2068 $\mu \mathrm{g} / \mathrm{kg})$, FB2 33.9\% (49-2442 $\mu \mathrm{g} / \mathrm{kg})$, T-2 16.9\% (3-73 $\mu \mathrm{g} / \mathrm{kg}$ ), while AFB1, AFB2, AFG1, AFG2, and OTA were not detected. The average value of all positive samples for the presence of the most common mycotoxin DON was $589 \mu \mathrm{g} / \mathrm{kg}$, and the highest value of $4902 \mu \mathrm{g} / \mathrm{kg}$ was found in the maize sample. A total of 10 cereal samples (all maize) did not comply with the highest permitted values for mycotoxins in foodstuff given in Commission Regulation (EC) No. 1881/2006 [10] and Commission Recommendation 2013/165/EU [11]. Distribution of mycotoxin occurrence is shown in Figure 1.

Table 1. Occurrence of regulated mycotoxins in Croatian cereals.

\begin{tabular}{|c|c|c|c|c|}
\hline \multirow[t]{2}{*}{ Compound } & \multicolumn{2}{|c|}{ Maize $(n=61)$} & \multicolumn{2}{|c|}{ Wheat $(n=57)$} \\
\hline & $\mathrm{F} \%(n)$ & $\begin{array}{l}\text { Median conc. } \mu \mathrm{g} / \mathrm{kg} \\
(\mathrm{min} .-\mathrm{max} . \text { conc.) }\end{array}$ & $\mathrm{F} \%(n)$ & $\begin{array}{l}\text { Median conc. } \mu \mathrm{g} / \mathrm{kg} \\
(\mathrm{min} .-\mathrm{max} . \text { conc.) }\end{array}$ \\
\hline Aflatoxin B1 & $<\mathrm{LOD}$ & $<\mathrm{LOD}$ & $<\mathrm{LOD}$ & $<\mathrm{LOD}$ \\
\hline Aflatoxin B2 & $<\mathrm{LOD}$ & $<\mathrm{LOD}$ & $<\mathrm{LOD}$ & $<\mathrm{LOD}$ \\
\hline Aflatoxin G1 & $<\mathrm{LOD}$ & $<\mathrm{LOD}$ & $<\mathrm{LOD}$ & $<\mathrm{LOD}$ \\
\hline Aflatoxin G2 & $<\mathrm{LOD}$ & $<\mathrm{LOD}$ & $<\mathrm{LOD}$ & $<\mathrm{LOD}$ \\
\hline Deoxynivalenol & $78.7(48)$ & $356(68-4902)$ & $68.4(39)$ & $175(63-867)$ \\
\hline Fumonisin B1 & $83.6(51)$ & 427 (61-9344) & $<\mathrm{LOD}$ & $<$ LOD \\
\hline Fumonisin B2 & $65.6(40)$ & $170(49-2442)$ & $<\mathrm{LOD}$ & $<$ LOD \\
\hline Zearalenone & $73.8(43)$ & $21(10-2068)$ & $<\mathrm{LOD}$ & $<\mathrm{LOD}$ \\
\hline $\mathrm{T}-2$ toxin & $32.8(20)$ & $4(3-73)$ & $<\mathrm{LOD}$ & $<\mathrm{LOD}$ \\
\hline HT-2 toxin & $88.5(54)$ & $5(3-41)$ & $<\mathrm{LOD}$ & $<\mathrm{LOD}$ \\
\hline Ochratoxin A & $<$ LOD & $<\mathrm{LOD}$ & $<\mathrm{LOD}$ & $<\mathrm{LOD}$ \\
\hline
\end{tabular}

n-number of samples; F-frequency (occurrence), number of samples with mycotoxin concentration above detection limit; $<$ LOD—below detection limit.
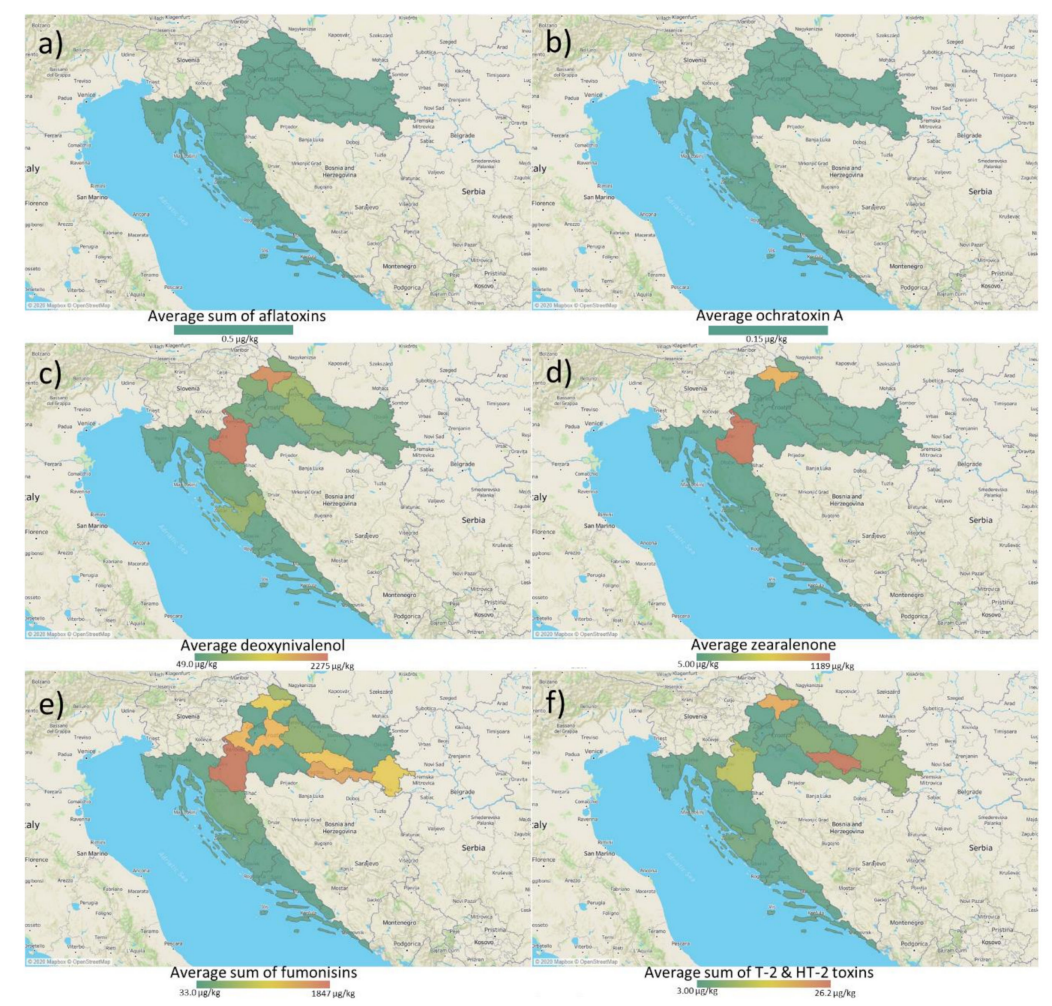

Figure 1. Distribution of regulated mycotoxin occurrence in Croatian cereals: (a) sum of aflatoxins (not detected); (b) ochratoxin A; (c) deoxynivalenol; (d) zearalenone; (e) sum of fumonisin B1 and B2; (f) sum of T-2 and HT-2 toxins. The map shows the averages of detected mycotoxins per county. 
The dominant occurrence of DON in cereals from Croatian field was confirmed by other authors. Španić et al. (2019) [18] investigated Fusarium head blight in different wheat varieties of the seasons 2015/2016 and 2016/2017. Among determined Fusarium mycotoxins, DON was quantified in all of the control samples. Habshied et al. (2019) [19] studied the occurrence of regulated and unregulated Fusarium mycotoxins in six barley cultivars during the years 2016-2018. Among investigated mycotoxins, DON proved to be the most dominant, however, found levels were not exceeding the EU regulation. Pleadin et al. (2017) [33] investigated the occurrence of selected regulated mycotoxins in Croatian cereals of 2015 harvest. DON was found to be the most frequent mycotoxin and maize the most contaminated cereal with $46 \%$ of samples non-compliant to the EU legislation. According to the authors, occurrence and found levels of mycotoxins can be correlated with weather conditions varying from year to year: in the case of Fusarium mycotoxins, their occurrence is favored by periods of rain accompanied with moderate air temperature during plant flowering. Earlier studies showed significant contamination of Croatian cereals and feedstuff with aflatoxins, namely AFB1, associated with climatic conditions, i.e., periods of extremely hot and dry weather during the critical stages of plant growth $[16,34,35]$.

\subsection{Pesticide Residues in Croatian Cereals}

Out of 333 analyzed substances, at least one pesticide residue was found and quantified in $31.8 \%$ of the cereal samples tested for pesticides, including fungicides carboxin, epoxiconazole and tebuconazole, insecticides chlorpyrifos, cypermethrin, pirimiphosmethyl, thiamethoxam, and thiofanox, as well as pesticide synergist piperonyl butoxide (Table 2). Piperonyl butoxide and cypermethrin were the most occurring substances both present in $9.1 \%$ of the analyzed samples in concentrations of $0.015-0.028 \mathrm{mg} / \mathrm{kg}$ and $0.055-0.058 \mathrm{mg} / \mathrm{kg}$, respectively, followed by epoxiconazole (0.020), pyrimiphos-methyl (0.021), carboxin $(0.077 \mathrm{mg} / \mathrm{kg})$, tebuconazole $(0.010 \mathrm{mg} / \mathrm{kg})$, chlorpyrifos $(0.010 \mathrm{mg} / \mathrm{kg})$, thiamethoxam $(0.010 \mathrm{mg} / \mathrm{kg})$, and thiofanox $(0.083 \mathrm{mg} / \mathrm{kg})$ present in $4.5 \%$ of all cereal samples. Distribution of sum of pesticide residues occurrence is represented in Figure 2. The sum of pesticide residue was used, as there was always maximum one pesticide positive sample per county.

Table 2. Occurrence of the found pesticide residues in Croatian cereals.

\begin{tabular}{|c|c|c|c|c|}
\hline \multirow[t]{2}{*}{ Compound } & \multicolumn{2}{|c|}{ Maize $(n=15)$} & \multicolumn{2}{|c|}{ Wheat $(n=7)$} \\
\hline & $\mathrm{F} \%(n)$ & $\begin{array}{l}\text { Median conc. } \mathrm{mg} / \mathrm{kg} \\
(\text { min. }- \text { max. conc. })\end{array}$ & $\mathrm{F} \%(n)$ & $\begin{array}{l}\text { Median conc. } \mathrm{mg} / \mathrm{kg} \\
\text { (min.-max. conc.) }\end{array}$ \\
\hline Piperonyl butoxide & $13.3(2)$ & $0.022(0.015-0.028)$ & $<$ LOD & $<\mathrm{LOD}$ \\
\hline Chlorpyriphos & $<$ LOD & $<\mathrm{LOD}$ & $14.3(1)$ & 0.010 \\
\hline Epoxiconazole & $<\mathrm{LOD}$ & $<\mathrm{LOD}$ & $14.3(1)$ & 0.020 \\
\hline Thiofanox & $6.7(1)$ & 0.083 & $<\mathrm{LOD}$ & $<\mathrm{LOD}$ \\
\hline Tebuconazole & $6.7(1)$ & 0.010 & $<$ LOD & $<\mathrm{LOD}$ \\
\hline Thiametoxam & $6.7(1)$ & 0.010 & $<\mathrm{LOD}$ & $<$ LOD \\
\hline Carboxin & $6.7(1)$ & 0.077 & $<$ LOD & $<\mathrm{LOD}$ \\
\hline Cypermethrin & $6.7(1)$ & 0.055 & $14.3(1)$ & 0.058 \\
\hline Pyrimiphos-methyl & $6.7(1)$ & 0.021 & $<$ LOD & $<\mathrm{LOD}$ \\
\hline
\end{tabular}

n-number of samples; F-frequency (occurrence), number of samples with mycotoxin concentration above detection limit; <LOD-below detection limit.

The sample with highest pesticide residues contamination was maize, containing four of the nine quantified substances: thiofanox at $0.083 \mathrm{mg} / \mathrm{kg}$, tebuconazole $0.010 \mathrm{mg} / \mathrm{kg}$, thiamethoxam $0.010 \mathrm{mg} / \mathrm{kg}$, and carboxin $0.077 \mathrm{mg} / \mathrm{kg}$. Out of all analyzed samples, the mentioned maize sample, originating from Vukovar-Srymia county, did not comply with the EU legislation regarding the maximum pesticide residue level permitted [24], containing elevated level of insecticide thiofanox $(0.083 \mathrm{mg} / \mathrm{kg})$. 


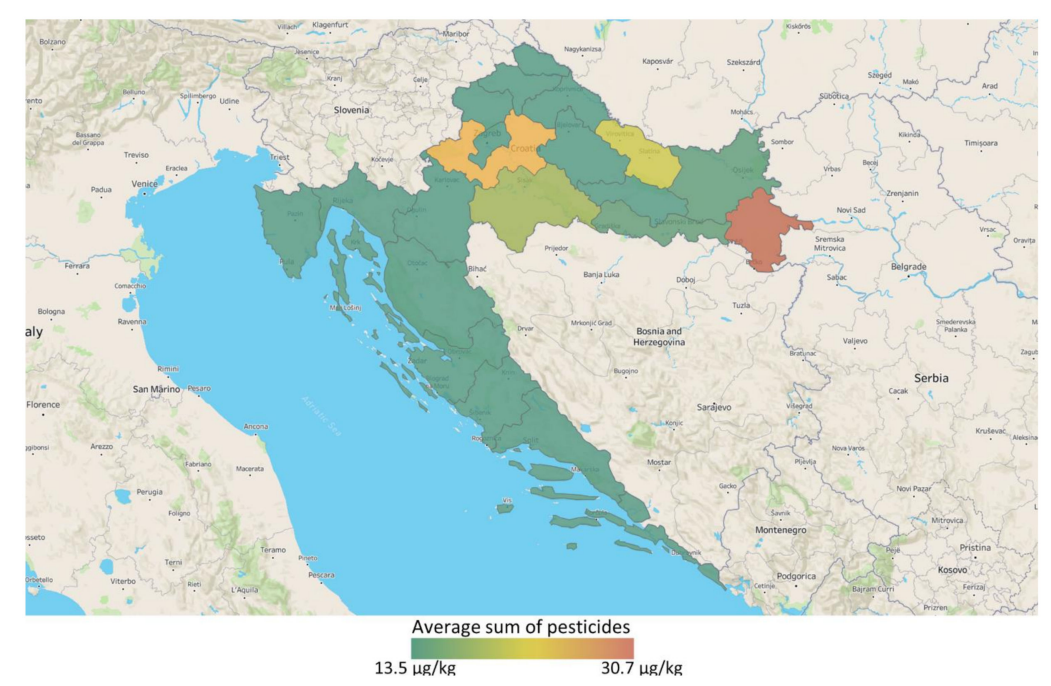

Figure 2. Occurrence of pesticides in Croatian cereals. The map shows the averages of sum of all detected pesticides per County.

The (elevated) presence of residue thiofanox is considered unusual, since it is an unapproved active substance according to the EU Pesticide database and plant protection agent containing thiofanox is not on the List of registered plant protection products according to the Croatian Ministry of Agriculture. Piperonyl butoxide, a semi-synthetic synergist, is particularly used in natural pyrethrum and synthetic pyrethroid insecticides, but it can occur in other agents and as such it is used for crop treatments, stored grain protection, disinfestation of grain storage facilities and indoor uses [36], thus having a possibility of contaminating cereal-based food. Its presence in various products clearly indicates the usage of plant protective agents, which is particularly important in the control of organic food production. In cereal samples, piperonyl butoxide was co-occurring with insecticide pyrimiphos-methyl. The quantified fungicides carboxin, epoxiconazole, and tebuconazole are found to affect the growth of certain mycotoxigenic fungi, and thus the occurrence of certain mycotoxins [37]. The fact that the analyzed samples containing the above-mentioned active substances were contaminated with low concentrations of the regulated mycotoxins confirms the finding of their fungicidal action. The occurrence of pyrimiphos-methyl and chlorpyriphos in wheat is especially worrying since they have shown high cytotoxinc effect in study by Clarke et al. (2015) [3].

Investigation of the pesticide residues in foodstuff from Croatian markets, including cereals and products thereof, conducted by Miloš et al. (2014) [38], showed a small percentage of non-compliant samples regarding the EU established MRLs, and none of the cereals samples. Pesticide residue levels in foods on the European market is annually reported by EFSA, based on data from the official national control activities carried out by EU Member States, Iceland, and Norway, and includes a subset of data from the EU-coordinated control program. In 2016, out of 608 cereal sample analyzed, $34.9 \%$ contained one or several pesticides in quantifiable concentrations. The residue concentrations exceeded the MRLs in $0.7 \%$ of the samples, containing pirimiphos-methyl, permethrin, hexaconazole or dichlorvos. In total, 19 different pesticide residues were quantified [24]. For year 2017, EFSA (2019) [39] reported multiple residues in $12.9 \%$ of analyzed rye samples, and $16.3 \%$ of analyzed rice samples. The residue concentrations exceeded the MRLs in $5.1 \%$ of the rice samples for 12 different pesticides, including not approved active substances acephate, carbendazim, hexaconazole, methamidophos, permethrin, profenofos, and triazophos. In rye samples, the residue concentrations exceeded the MRLs in $1.9 \%$ of the analyzed samples, containing chlorpyrifos, glyphosate, permethrin, pirimiphos-methy, and tebuconazole. A total of 676 unprocessed cereal samples were analyzed in 2018, of which $24.7 \%$ were characterized as non-compliant, with active substance tricyclazole being the most occurring [40]. Comparing the abovementioned data with the occurrence data gathered in our investigation, 
insecticides were the most commonly found pesticide residues in cereals in both cases, and often the reason for exceeding the EU MRLs. Even though a significant occurrence of pesticide residues was observed (up to $34.9 \%$ ), only a small percentage of samples was reported as non-compliant, roughly to the value of $5 \%$, which is in accordance with our investigation results.

\subsection{Heavy Metals in Croatian Cereals}

The majority (90.9\%) of cereal samples analyzed for heavy metals contained $\mathrm{Hg}$ in concentrations above LOQ $(0.009-0.016 \mathrm{mg} / \mathrm{kg})$, with highest concentrations found in analyzed maize samples. Cd was quantified in $27.3 \%$ of samples $(0.007-0.080 \mathrm{mg} / \mathrm{kg}$ ), all of which were wheat originating from all Croatian regions, while $\mathrm{Pb}$ and As were not found. Regarding the determined concentrations of heavy metals, all of the analyzed cereal samples complied with the highest permitted levels for cereals set by the EU legislation [10], which are $0.20 \mathrm{mg} / \mathrm{kg}$ for $\mathrm{Pb}, 0.10$, and $0.20 \mathrm{mg} / \mathrm{kg}$ for Cd. Although levels of $\mathrm{Hg}$ and $\mathrm{As}$ are not regulated for cereals, they are often sought to be analyzed when food and feed safety is to be determined. The results of heavy metals occurrence investigation are represented in Table 3 and the County specific occurrence data distribution shown in Figure 3.

Table 3. Heavy metals occurrence in Croatian cereals.

\begin{tabular}{|c|c|c|c|c|}
\hline \multirow[t]{2}{*}{ Compound } & \multicolumn{2}{|c|}{ Maize ( $n=15)$} & \multicolumn{2}{|c|}{ Wheat $(n=7)$} \\
\hline & $\mathrm{F} \%(n)$ & $\begin{array}{l}\text { Median conc. } \mathrm{mg} / \mathrm{kg} \\
\text { (min.-max. conc.) }\end{array}$ & $\mathrm{F} \%(n)$ & $\begin{array}{l}\text { Median conc. } \mathrm{mg} / \mathrm{kg} \\
\text { (min.-max. conc.) }\end{array}$ \\
\hline Lead & $<$ LOD & $<\mathrm{LOD}$ & $<$ LOD & $<$ LOD \\
\hline Cadmium & $<\mathrm{LOD}$ & $<\mathrm{LOD}$ & $85.7(6)$ & $0.042(0.007-0.080)$ \\
\hline Arsenic & $<$ LOD & $<\mathrm{LOD}$ & $<\mathrm{LOD}$ & $<\mathrm{LOD}$ \\
\hline Mercury & $86.7(13)$ & $0.014(0.011-0.016)$ & $100.0(7)$ & $0.012(0.009-0.014)$ \\
\hline
\end{tabular}

$n$-number of samples; F-frequency (occurrence), number of samples with mycotoxin concentration above detection limit; $<$ LOD—below detection limit.
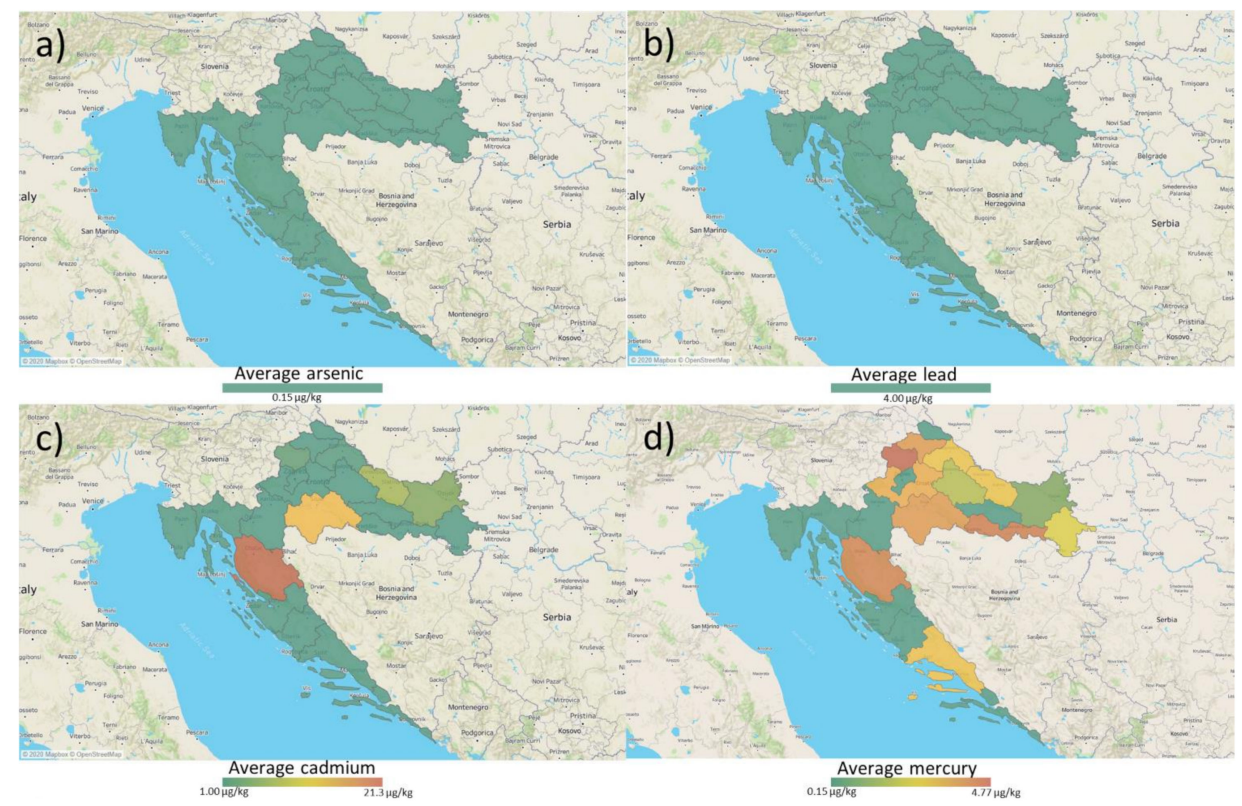

Figure 3. Distribution of heavy metals occurrence in Croatian cereals: (a) Arsenic (below limit of detection); (b) Lead (below limit of detection; (c) Cadmium; (d) Mercury. The map shows the averages of detected heavy metals per County.

According to the annual reports of Rapid Alert System for Feed and Feed for years 2016, 2017 and 2018, Hg, Pb and Cd are predominately notified [41-43], however the risk 
posed by heavy metals is mainly related to fish and fish products. To the best of our knowledge, data on heavy metals occurrence in Croatian cereals are lacking.

\section{Conclusions}

An occurrence investigation study of mycotoxins, pesticide residues, and heavy metals in Croatian cereals was performed using validated analytical UHPLC-MS/MS, GC-MS/MS and AAS methods. Fusarium mycotoxins were the most common mycotoxins found in all collected samples of different cultures, with DON being the most frequent mycotoxin occurring in the $73.7 \%$ of samples, while aflatoxins and OTA were not found. Among heavy metals, $\mathrm{Hg}$ and $\mathrm{Cd}$ were the most occurring, while $\mathrm{Pb}$ and As were not detected. A total of $31.8 \%$ of samples analyzed for pesticides contained at least one pesticide residue, with synergist piperonyl butoxide and insecticide cypermethrin being the most occurring residues each present in $9.1 \%$ of the samples.

Only a small percentage of the samples was non-compliant to the EU legislation for food: $8.5 \%$ regarding mycotoxins, $4.5 \%$ regarding pesticide residues, but none regarding heavy metals. In addition, the unusual presence of thiofanox, not approved active substance according to the EU Pesticide database, and the unusual presence of $\mathrm{Hg}$ in all analyzed samples was recorded. Accordingly, the results of the conducted multi-contaminant analysis of Croatian cereals indicate the importance and necessity of constant and continuous control of food and feed safety, including contaminant analysis, in order to collect enough occurrence data for proper risk assessment that these contaminants represent for the consumer's health.

This very valuable data can serve as the identified mixture of food contaminants for further toxicological studies and better risk assessment for the consumers.

Author Contributions: Conceptualization, methodology and visualization, M.K., T.K., I.D.Š. and B.Š.; validation, formal analysis and investigation, M.K., M.B., J.J., T.R. and A.N.; resources and supervision, A.N.; writing—original draft preparation, M.K. and M.B.; writing—review and editing, T.K., I.D.Š. and B.Š. All authors have read and agreed to the published version of the manuscript.

Funding: This research received no external funding.

Institutional Review Board Statement: Not applicable.

Informed Consent Statement: Not applicable.

Data Availability Statement: The data presented in this study are openly available.

Conflicts of Interest: The authors declare no conflict of interest.

\section{Appendix A}

Table A1. UHPLC-MS/MS parameters optimized for mycotoxin determination.

\begin{tabular}{|c|c|c|c|c|c|c|c|}
\hline $\begin{array}{l}\text { Compound } \\
\text { Name }\end{array}$ & $\begin{array}{l}\text { Retention } \\
\text { Time } \\
\text { (min) }\end{array}$ & $\begin{array}{c}\text { Precursor } \\
\text { Ion } \\
(m / z)\end{array}$ & $\begin{array}{c}\text { Cone } \\
\text { Voltage } \\
\text { (V) }\end{array}$ & $\begin{array}{c}\text { Primary } \\
\text { Production } \\
(\mathrm{m} / \mathrm{z})\end{array}$ & $\begin{array}{l}\text { Collision } \\
\text { Energy } \\
\text { (V) }\end{array}$ & $\begin{array}{c}\text { Secondary } \\
\text { Production } \\
(\mathrm{m} / \mathrm{z})\end{array}$ & $\begin{array}{c}\text { Collision } \\
\text { Energy } \\
\text { (V) }\end{array}$ \\
\hline Aflatoxin B1 & 8.7 & 313.0 & 60 & 241.0 & 38 & 285.0 & 23 \\
\hline Aflatoxin B2 & 8.5 & 315.0 & 60 & 259.0 & 30 & 287.0 & 25 \\
\hline Aflatoxin G1 & 8.1 & 329.0 & 60 & 243.0 & 28 & 311.0 & 24 \\
\hline Aflatoxin G2 & 7.8 & 331.0 & 60 & 313.0 & 24 & 313.0 & 24 \\
\hline Deoxynivalenol & 4.7 & 297.0 & 25 & 231.0 & 25 & 249.0 & 10 \\
\hline Fumonisin B1 & 9.4 & 722.4 & 20 & 334.3 & 40 & 352.3 & 40 \\
\hline Fumonisin B2 & 10.4 & 706.4 & 50 & 336.2 & 40 & 318.2 & 40 \\
\hline Zearalenone & 10.5 & 317.1 & -58 & 131.0 & -30 & 175.0 & -20 \\
\hline $\mathrm{T}-2$ toxin & 10.1 & 484.7 & 25 & 185.0 & 30 & 215.0 & 20 \\
\hline HT-2 toxin & 9.6 & 442.6 & 25 & 263.4 & 10 & 215.3 & 15 \\
\hline Ochratoxin A & 9.5 & 404.1 & 30 & 215.3 & 15 & 239.0 & 24 \\
\hline
\end{tabular}


Table A2. UHPLC-MS/MS parameters optimized for pesticide residues determination.

\begin{tabular}{|c|c|c|c|c|c|c|c|}
\hline Compound Name & $\begin{array}{l}\text { Retention } \\
\text { Time } \\
\text { (min) }\end{array}$ & $\begin{array}{c}\text { Precursor } \\
\text { Ion } \\
(m / z)\end{array}$ & $\begin{array}{c}\text { Cone } \\
\text { Voltage (V) }\end{array}$ & $\begin{array}{c}\text { Primary } \\
\text { Production } \\
(\mathrm{m} / \mathrm{z})\end{array}$ & $\begin{array}{c}\text { Collision } \\
\text { Energy (V) }\end{array}$ & $\begin{array}{c}\text { Secondary } \\
\text { Production } \\
(\mathrm{m} / \mathrm{z})\end{array}$ & $\begin{array}{c}\text { Collision } \\
\text { Energy (V) }\end{array}$ \\
\hline Acephate & 1.7 & 184.1 & 18 & 49.0 & 18 & 143.0 & 8 \\
\hline Acetamiprid & 4.8 & 223.0 & 23 & 126.0 & 20 & 56.1 & 15 \\
\hline Acibenzolar-S-metil & 6.6 & 210.9 & 43 & 135.9 & 29 & 91.0 & 20 \\
\hline Aldicarb & 4.9 & 208.0 & 16 & 116.1 & 6 & 89.1 & 12 \\
\hline Aldicarb sulfone & 3.3 & 240.0 & 18 & 148.0 & 14 & 86.0 & 20 \\
\hline Aldicarb sulfoxide & 3.5 & 207.0 & 24 & 132.0 & 6 & 89.0 & 12 \\
\hline Ametryn & 6.0 & 228.1 & 45 & 186.1 & 18 & 96.0 & 30 \\
\hline Aminocarb & 3.0 & 209.1 & 35 & 152.0 & 14 & 137.1 & 25 \\
\hline Amitraz & 7.8 & 294.0 & 40 & 148.0 & 18 & 91.1 & 45 \\
\hline Azoxystrobin & 6.4 & 404.1 & 25 & 372.0 & 15 & 344.0 & 25 \\
\hline Benalaxyl & 7.8 & 326.1 & 30 & 148.0 & 20 & 91.0 & 35 \\
\hline Bendiocarb & 5.2 & 224.1 & 24 & 167.0 & 8 & 109.0 & 18 \\
\hline Benzoximate & 8.3 & 364.0 & 18 & 199.1 & 10 & 105.0 & 20 \\
\hline Bifenazate & 6.8 & 301.1 & 25 & 198.0 & 8 & 170.0 & 20 \\
\hline Bitertanol & 8.4 & 338.1 & 15 & 99.1 & 16 & 269.2 & 10 \\
\hline Boscalid & 6.6 & 342.9 & 35 & 307.0 & 18 & 139.9 & 18 \\
\hline Bromuconazole 1 & 7.0 & 378.0 & 40 & 159.0 & 25 & 70.0 & 20 \\
\hline Bromuconazole 2 & 8.1 & 378.0 & 40 & 159.0 & 25 & 70.0 & 20 \\
\hline Bupirimate & 7.1 & 317.0 & 32 & 108.0 & 30 & 166.0 & 26 \\
\hline Buprofezin & 9.3 & 306.1 & 26 & 201.0 & 11 & 116.2 & 16 \\
\hline Butafenacil & 6.8 & 492.0 & 25 & 331.0 & 25 & 180.0 & 45 \\
\hline Butocarboxim & 4.9 & 213.0 & 35 & 75.0 & 15 & 116.0 & 10 \\
\hline Butoxycarboxim & 3.2 & 223.0 & 27 & 106.0 & 8 & 166.0 & 8 \\
\hline Carbaryl & 5.5 & 202.0 & 24 & 145.0 & 10 & 127.0 & 24 \\
\hline Carbendazim & 3.9 & 192.1 & 35 & 160.1 & 17 & 132.1 & 28 \\
\hline Carbetamide & 5.0 & 237.0 & 22 & 192.0 & 8 & 118.0 & 12 \\
\hline Carbofuran & 5.3 & 222.1 & 26 & 165.1 & 12 & 123.0 & 21 \\
\hline $\begin{array}{l}\text { Carbofuran-3- } \\
\text { hidroxy }\end{array}$ & 4.4 & 238.0 & 27 & 163.0 & 16 & 181.0 & 11 \\
\hline Carboxin & 5.4 & 236.0 & 32 & 143.0 & 16 & 87.0 & 24 \\
\hline Carfentrazone-ethyl & 7.4 & 412.0 & 45 & 346.0 & 20 & 366.0 & 15 \\
\hline Chlorantraniliprole & 6.0 & 483.8 & 25 & 285.8 & 18 & 452.8 & 16 \\
\hline Chlorfluazuron & 11.0 & 539.8 & 38 & 382.9 & 22 & 158.0 & 22 \\
\hline Chlorotoluron & 5.8 & 213.0 & 33 & 72.0 & 16 & 46.0 & 15 \\
\hline Chloroxuron & 7.2 & 291.1 & 36 & 72.0 & 18 & 218.1 & 25 \\
\hline Chlorpyrifos & 9.9 & 349.9 & 29 & 97.0 & 32 & 198.0 & 18 \\
\hline Clethodim & 8.8 & 360.0 & 26 & 164.0 & 20 & 268.1 & 11 \\
\hline Clofentezine & 8.7 & 303.0 & 25 & 138.0 & 15 & 102.0 & 35 \\
\hline Clomazone & 6.2 & 240.0 & 30 & 125.0 & 18 & 89.0 & 46 \\
\hline Clothianidin & 4.4 & 250.0 & 25 & 169.0 & 15 & 132.0 & 17 \\
\hline Cyazofamid & 7.2 & 325.0 & 24 & 107.9 & 13 & 261.0 & 10 \\
\hline Cycluron & 6.2 & 199.0 & 36 & 89.1 & 14 & 69.2 & 21 \\
\hline Cymoxanil & 4.6 & 199.0 & 20 & 128.0 & 8 & 111.0 & 18 \\
\hline Cyproconazole & 6.8 & 292.2 & 32 & 70.2 & 20 & 125.1 & 25 \\
\hline Cyprodinil & 7.5 & 226.0 & 40 & 93.0 & 33 & 77.0 & 38 \\
\hline Cyromazine & 1.4 & 167.0 & 40 & 85.0 & 18 & 60.0 & 18 \\
\hline Desmedipham & 5.8 & 318.1 & 25 & 182.0 & 10 & 154.0 & 22 \\
\hline Diclobutrazol & 7.5 & 328.0 & 35 & 70.0 & 25 & 59.1 & 25 \\
\hline Dicrotophos & 4.4 & 238.0 & 24 & 112.0 & 9 & 193.0 & 11 \\
\hline Diethofencarb & 6.2 & 268.0 & 21 & 226.0 & 10 & 124.0 & 32 \\
\hline Difenoconazole & 9.3 & 406.0 & 35 & 251.1 & 25 & 253.1 & 25 \\
\hline Diflubenzuron & 7.4 & 311.1 & 30 & 158.1 & 14 & 141.0 & 30 \\
\hline Dimethoate & 4.4 & 230.1 & 25 & 199.0 & 10 & 125.0 & 20 \\
\hline Dimethomorph & 6.9 & 388.1 & 38 & 300.9 & 22 & 165.0 & 28 \\
\hline Dimoxystrobin & 7.5 & 327.1 & 22 & 205.2 & 10 & 116.1 & 18 \\
\hline Diniconazole & 8.4 & 326.0 & 45 & 70.2 & 25 & 159.0 & 35 \\
\hline
\end{tabular}


Table A2. Cont.

\begin{tabular}{|c|c|c|c|c|c|c|c|}
\hline Compound Name & $\begin{array}{l}\text { Retention } \\
\text { Time } \\
\text { (min) }\end{array}$ & $\begin{array}{c}\text { Precursor } \\
\text { Ion } \\
(m / z)\end{array}$ & $\begin{array}{c}\text { Cone } \\
\text { Voltage (V) }\end{array}$ & $\begin{array}{c}\text { Primary } \\
\text { Production } \\
(m / z)\end{array}$ & $\begin{array}{c}\text { Collision } \\
\text { Energy (V) }\end{array}$ & $\begin{array}{c}\text { Secondary } \\
\text { Production } \\
(m / z)\end{array}$ & $\begin{array}{c}\text { Collision } \\
\text { Energy (V) }\end{array}$ \\
\hline Dinotefuran & 3.3 & 203.0 & 22 & 129.0 & 14 & 157.0 & 6 \\
\hline Dioxacarb & 4.5 & 224.1 & 25 & 123.1 & 17 & 167.1 & 8 \\
\hline Diuron & 5.6 & 233.0 & 32 & 72.1 & 16 & 46.3 & 14 \\
\hline Doramectin & 11.4 & 916.6 & 20 & 593.4 & 10 & 331.2 & 20 \\
\hline $\begin{array}{c}\text { Emamectin } \\
\text { benzoate b1a }\end{array}$ & 10.4 & 886.6 & 70 & 158.0 & 40 & 126.0 & 40 \\
\hline $\begin{array}{c}\text { Emamectin } \\
\text { benzoate b1b }\end{array}$ & 10.0 & 872.6 & 68 & 158.2 & 38 & 126.2 & 48 \\
\hline Epoxiconazole & 7.5 & 330.0 & 30 & 101.0 & 45 & 121.0 & 25 \\
\hline Eprinomectin & 11.1 & 915.6 & 20 & 186.0 & 35 & 154.0 & 35 \\
\hline Etaconazole & 7.5 & 328.1 & 45 & 159.0 & 30 & 205.0 & 15 \\
\hline Ethiofencarb & 5.5 & 226.1 & 20 & 107.0 & 15 & 164.0 & 8 \\
\hline Ethiprole & 6.3 & 414.1 & 12 & 350.9 & 25 & 396.9 & 9 \\
\hline Ethirimol & 4.9 & 210.1 & 48 & 140.0 & 22 & 98.0 & 28 \\
\hline Ethofumesate & 6.1 & 287.1 & 36 & 121.1 & 16 & 259.1 & 9 \\
\hline Etoxazole & 10.6 & 360.1 & 36 & 141.0 & 36 & 57.2 & 32 \\
\hline Famoxadone & 8.0 & 392.2 & 20 & 331.1 & 8 & 238.0 & 18 \\
\hline Fenamidone & 6.3 & 312.1 & 26 & 92.0 & 23 & 236.1 & 12 \\
\hline Fenarimol & 7.1 & 331.0 & 45 & 268.0 & 22 & 81.0 & 32 \\
\hline Fenazaquin & 11.3 & 307.2 & 35 & 57.2 & 22 & 161.0 & 15 \\
\hline Fenbuconazole & 7.5 & 337.0 & 40 & 70.1 & 20 & 125.0 & 30 \\
\hline Fenhexamid & 6.8 & 302.1 & 60 & 97.2 & 25 & 55.3 & 38 \\
\hline Fenobucarb & 6.1 & 208.0 & 26 & 94.9 & 14 & 152.0 & 8 \\
\hline Fenoxycarb & 7.4 & 302.1 & 30 & 116.1 & 10 & 88.0 & 17 \\
\hline Fenpropimorph & 6.2 & 304.2 & 50 & 147.1 & 28 & 57.2 & 30 \\
\hline Fenpyroximat & 11.0 & 422.2 & 35 & 366.1 & 15 & 138.1 & 35 \\
\hline Fenuron & 4.5 & 165.0 & 27 & 71.9 & 16 & 45.9 & 14 \\
\hline Fipronil & 7.0 & 436.8 & 42 & 367.8 & 16 & 290.0 & 26 \\
\hline Flonicamid & 3.4 & 230.1 & 40 & 203.1 & 18 & 174.0 & 16 \\
\hline Fluazinam & 9.7 & 462.7 & -45 & 415.7 & -20 & 397.8 & -15 \\
\hline Flubendiamide & 7.4 & 683.1 & 22 & 408.0 & 12 & 274.1 & 29 \\
\hline Fludioxonil & 6.4 & 247.0 & -42 & 126.0 & -35 & 180.0 & -28 \\
\hline Flufenacet & 6.8 & 364.0 & 20 & 152.1 & 19 & 194.1 & 10 \\
\hline Flufenoxuron & 10.7 & 489.1 & 36 & 158.0 & 22 & 141.0 & 48 \\
\hline Fluomethuron & 5.7 & 233.2 & 34 & 72.2 & 16 & 46.4 & 15 \\
\hline Fluoxastrobin & 7.2 & 459.0 & 40 & 427.0 & 15 & 188.0 & 38 \\
\hline Fluquinconazole & 7.0 & 376.0 & 45 & 348.8 & 16 & 306.9 & 28 \\
\hline Flurochloridone & 6.7 & 312.0 & 40 & 292.0 & 20 & 145.0 & 50 \\
\hline Flusilazole & 7.6 & 316.0 & 40 & 247.0 & 20 & 165.0 & 25 \\
\hline Flutolanil & 6.4 & 324.1 & 38 & 242.1 & 24 & 65.0 & 42 \\
\hline Flutriafol & 5.7 & 302.1 & 30 & 70.2 & 18 & 123.1 & 35 \\
\hline Forchlorfenuron & 5.9 & 248.1 & 32 & 129.0 & 16 & 93.0 & 31 \\
\hline Fuberidazol & 4.6 & 185.0 & 45 & 157.0 & 22 & 65.0 & 40 \\
\hline Furalaxyl & 6.2 & 302.1 & 25 & 95.0 & 25 & 242.0 & 15 \\
\hline Furathiocarb & 9.5 & 383.2 & 30 & 194.9 & 18 & 252.0 & 12 \\
\hline Halofenozide & 6.1 & 331.1 & 15 & 104.9 & 20 & 275.0 & 5 \\
\hline Hexaconazole & 8.2 & 314.0 & 35 & 70.1 & 20 & 159.0 & 35 \\
\hline Hexythiazox & 10.1 & 353.0 & 32 & 228.1 & 14 & 168.1 & 24 \\
\hline Hydramethylnon & 10.6 & 495.2 & 78 & 323.3 & 30 & 151.1 & 60 \\
\hline Imazalil & 5.7 & 297.0 & 40 & 159.0 & 18 & 69.0 & 20 \\
\hline Imidacloprid & 4.6 & 256.1 & 26 & 209.1 & 20 & 175.1 & 18 \\
\hline Indoxacarb & 8.8 & 528.0 & 32 & 150.0 & 25 & 218.0 & 24 \\
\hline Ipconazole & 9.1 & 334.2 & 40 & 70.0 & 28 & 125.0 & 40 \\
\hline Iprovalicarb & 6.6 & 321.1 & 26 & 119.1 & 18 & 203.1 & 8 \\
\hline Isocarbofos & 5.7 & 307.1 & 12 & 230.9 & 15 & $291.1>231.1$ & 13 \\
\hline Isoprocarb & 5.6 & 194.1 & 24 & 95.1 & 14 & 137.1 & 8 \\
\hline Isoproturon & 6.0 & 207.2 & 36 & 72.1 & 19 & 46.1 & 16 \\
\hline
\end{tabular}


Table A2. Cont.

\begin{tabular}{|c|c|c|c|c|c|c|c|}
\hline Compound Name & $\begin{array}{l}\text { Retention } \\
\text { Time } \\
\text { (min) }\end{array}$ & $\begin{array}{c}\text { Precursor } \\
\text { Ion } \\
(m / z)\end{array}$ & $\begin{array}{c}\text { Cone } \\
\text { Voltage (V) }\end{array}$ & $\begin{array}{c}\text { Primary } \\
\text { Production } \\
(m / z)\end{array}$ & $\begin{array}{c}\text { Collision } \\
\text { Energy (V) }\end{array}$ & $\begin{array}{c}\text { Secondary } \\
\text { Production } \\
(m / z)\end{array}$ & $\begin{array}{c}\text { Collision } \\
\text { Energy (V) }\end{array}$ \\
\hline Ivermectin & 11.6 & 892.6 & 15 & 307.2 & 20 & 569.4 & 15 \\
\hline Kresoxim-methyl & 7.4 & 314.1 & 20 & 206.0 & 20 & 116.0 & 5 \\
\hline Linuron & 6.5 & 249.1 & 35 & 160.0 & 18 & 182.0 & 16 \\
\hline Lufenuron & 10.6 & 511.2 & 40 & 158.0 & 22 & 141.0 & 48 \\
\hline Mandipropamid & 6.5 & 412.3 & 35 & 328.2 & 14 & 356.2 & 10 \\
\hline Mefenacet & 7.0 & 299.0 & 28 & 148.0 & 14 & 120.0 & 26 \\
\hline Mepanipyrim & 7.2 & 224.1 & 50 & 106.0 & 25 & 77.0 & 35 \\
\hline Mepronil & 6.4 & 270.1 & 30 & 119.0 & 25 & 91.0 & 38 \\
\hline Mesotrione & 4.8 & 340.1 & 38 & 104.0 & 30 & 228.1 & 18 \\
\hline Metaflumizone & 10.1 & 507.1 & 54 & 178.1 & 22 & 287.1 & 22 \\
\hline Metalaxyl & 5.8 & 280.1 & 26 & 220.1 & 14 & 192.1 & 18 \\
\hline Metconazole & 8.3 & 320.1 & 36 & 70.0 & 22 & 125.0 & 35 \\
\hline Methabenzthiazuron & 6.1 & 222.0 & 30 & 165.0 & 15 & 150.0 & 32 \\
\hline Methamidophos & 1.3 & 142.0 & 28 & 93.9 & 14 & 124.9 & 14 \\
\hline Methiocarb & 6.4 & 226.0 & 26 & 169.0 & 8 & 121.0 & 18 \\
\hline Methomyl & 3.8 & 163.1 & 16 & 106.0 & 10 & 88.1 & 10 \\
\hline Methoprotryne & 6.1 & 272.2 & 36 & 198.2 & 22 & 240.2 & 19 \\
\hline Methoxyfenozide & 6.5 & 369.1 & 15 & 149.1 & 20 & 313.2 & 5 \\
\hline Metobromuron & 5.8 & 259.1 & 31 & 148.1 & 15 & 170.0 & 19 \\
\hline Metolachlor & 7.1 & 284.1 & 22 & 252.1 & 16 & 176.1 & 26 \\
\hline Metribuzin & 5.2 & 215.0 & 38 & 187.1 & 19 & 84.1 & 19 \\
\hline Mevinphos & 4.5 & 225.1 & 24 & 127.1 & 12 & 193.1 & 6 \\
\hline Mexacarbate & 4.2 & 223.2 & 34 & 166.1 & 15 & 151.0 & 24 \\
\hline Monocrotophos & 4.1 & 224.1 & 24 & 127.1 & 18 & 98.1 & 12 \\
\hline Monolinuron & 5.6 & 215.0 & 30 & 126.0 & 17 & 148.0 & 14 \\
\hline Moxidectin & 11.5 & 640.5 & 25 & 528.4 & 10 & 498.3 & 15 \\
\hline Myclobutanil & 6.9 & 289.1 & 40 & 70.2 & 18 & 125.1 & 35 \\
\hline Neburon & 7.5 & 275.0 & 35 & 88.0 & 16 & 114.0 & 14 \\
\hline Nitenpyram & 3.7 & 271.1 & 35 & 224.9 & 12 & 125.9 & 35 \\
\hline Novaluron & 9.8 & 493.0 & 34 & 158.0 & 22 & 141.0 & 44 \\
\hline Nuarimol & 6.3 & 315.0 & 45 & 252.0 & 20 & 81.1 & 20 \\
\hline Omethoate & 2.6 & 214.1 & 24 & 183.1 & 12 & 125.1 & 22 \\
\hline Oxadixyl & 5.1 & 279.0 & 38 & 219.0 & 10 & 132.0 & 28 \\
\hline Oxamyl & 3.7 & 237.0 & 15 & 72.0 & 12 & 90.0 & 8 \\
\hline Paclobutrazol & 6.4 & 294.1 & 28 & 70.2 & 22 & 125.1 & 28 \\
\hline Penconazole & 8.2 & 284.0 & 35 & 70.1 & 25 & 159.0 & 25 \\
\hline Pencycuron & 8.4 & 329.1 & 35 & 125.0 & 22 & 218.0 & 15 \\
\hline Pendimethalin & 10.0 & 282.2 & 18 & 212.2 & 12 & 194.1 & 18 \\
\hline Phenmedipham & 6.0 & 301.2 & 32 & 168.0 & 8 & 107.9 & 32 \\
\hline Picoxystrobin & 7.4 & 368.0 & 18 & 145.1 & 22 & 205.1 & 8 \\
\hline Piperonyl butoxide & 9.8 & 356.3 & 20 & 176.9 & 10 & 119.0 & 36 \\
\hline Pirimicarb & 5.3 & 239.1 & 34 & 72.0 & 21 & 182.1 & 17 \\
\hline Prochloraz & 8.6 & 376.0 & 25 & 308.0 & 10 & 70.0 & 25 \\
\hline Promecarb & 6.5 & 208.1 & 25 & 109.0 & 16 & 151.0 & 8 \\
\hline Prometon & 5.7 & 226.0 & 42 & 142.0 & 22 & 86.3 & 28 \\
\hline Prometryn & 6.5 & 242.0 & 45 & 158.0 & 22 & 200.1 & 18 \\
\hline Propamocarb & 2.8 & 189.1 & 34 & 102.0 & 18 & 144.0 & 12 \\
\hline Propargite & 10.3 & 368.2 & 22 & 231.1 & 10 & 175.1 & 16 \\
\hline Propham & 5.5 & 180.0 & 14 & 138.0 & 8 & 120.0 & 16 \\
\hline Propiconazole & 8.3 & 342.0 & 45 & 69.0 & 20 & 159.0 & 35 \\
\hline Propoxur & 5.2 & 210.0 & 18 & 111.0 & 15 & 168.0 & 7 \\
\hline Prothioconazole & 7.8 & 344.0 & 24 & 125.1 & 30 & 188.9 & 22 \\
\hline Pymetrozine & 3.7 & 218.0 & 30 & 105.0 & 30 & 79.0 & 15 \\
\hline Pyracarbolid & 5.3 & 218.1 & 32 & 125.1 & 20 & 97.1 & 28 \\
\hline Pyraclostrobin & 8.3 & 388.1 & 24 & 193.9 & 12 & 163.0 & 26 \\
\hline Pyridaben & 11.0 & 365.1 & 25 & 147.1 & 26 & 309.1 & 12 \\
\hline Pyrimethanil & 6.4 & 200.0 & 52 & 107.0 & 24 & 82.0 & 28 \\
\hline
\end{tabular}


Table A2. Cont.

\begin{tabular}{|c|c|c|c|c|c|c|c|}
\hline Compound Name & $\begin{array}{l}\text { Retention } \\
\text { Time } \\
\text { (min) }\end{array}$ & $\begin{array}{c}\text { Precursor } \\
\text { Ion } \\
(m / z)\end{array}$ & $\begin{array}{c}\text { Cone } \\
\text { Voltage (V) }\end{array}$ & $\begin{array}{c}\text { Primary } \\
\text { Production } \\
(m / z)\end{array}$ & $\begin{array}{c}\text { Collision } \\
\text { Energy (V) }\end{array}$ & $\begin{array}{c}\text { Secondary } \\
\text { Production } \\
(m / z)\end{array}$ & $\begin{array}{c}\text { Collision } \\
\text { Energy (V) }\end{array}$ \\
\hline Pyriproxifen & 9.9 & 322.1 & 30 & 96.0 & 20 & 185.0 & 22 \\
\hline Quinoxyfen & 10.4 & 308.0 & 65 & 197.0 & 30 & 161.9 & 45 \\
\hline Rotenone & 7.6 & 395.0 & 45 & 213.1 & 25 & 192.1 & 25 \\
\hline Secbumeton & 5.8 & 226.2 & 38 & 170.2 & 18 & 100.2 & 26 \\
\hline Siduron & 6.2 & 233.0 & 38 & 93.8 & 22 & 137.0 & 16 \\
\hline Simetryn & 5.5 & 214.0 & 44 & 124.0 & 20 & 95.9 & 26 \\
\hline Spinetoram & 10.3 & 748.5 & 58 & 142.2 & 35 & 98.1 & 70 \\
\hline Spinosad A & 9.7 & 732.6 & 40 & 142.0 & 30 & 98.1 & 60 \\
\hline Spinosad D & 10.3 & 746.5 & 50 & 142.0 & 28 & 98.1 & 58 \\
\hline Spirodiclofen & 10.5 & 411.1 & 25 & 71.2 & 10 & 313.0 & 15 \\
\hline Spiromesifen & 10.2 & 371.1 & 15 & 273.1 & 10 & 255.1 & 25 \\
\hline Spirotetramat & 6.9 & 374.2 & 35 & 330.2 & 15 & 302.2 & 18 \\
\hline Spiroxamine & 6.7 & 298.0 & 40 & 144.0 & 18 & 100.0 & 30 \\
\hline Sulfentrazone & 5.3 & 387.0 & 50 & 307.1 & 20 & 146.0 & 44 \\
\hline Tebuconazole & 7.9 & 308.0 & 40 & 70.1 & 25 & 125.0 & 35 \\
\hline Tebufenozid & 7.2 & 353.1 & 18 & 133.0 & 18 & 297.1 & 6 \\
\hline Tebufenpyrad & 9.8 & 334.0 & 60 & 117.0 & 35 & 145.0 & 25 \\
\hline Tebuthiuron & 5.6 & 229.0 & 38 & 172.0 & 18 & 116.0 & 26 \\
\hline Teflubenzuron & 10.1 & 380.9 & 35 & 158.0 & 15 & 140.9 & 40 \\
\hline Temephos & 10.1 & 467.1 & 35 & 125.0 & 36 & 418.9 & 18 \\
\hline Terbumeton & 5.8 & 226.1 & 38 & 170.1 & 18 & 114.1 & 26 \\
\hline Terbuthylazine & 6.5 & 231.9 & 31 & 176.0 & 16 & 134.0 & 25 \\
\hline Terbutryn & 6.7 & 242.1 & 36 & 186.1 & 19 & 91.0 & 28 \\
\hline Tetraconazole & 7.1 & 372.0 & 45 & 159.0 & 30 & 70.1 & 20 \\
\hline Thiabendazole & 4.6 & 202.0 & 50 & 175.0 & 24 & 131.0 & 32 \\
\hline Thiacloprid & 5.1 & 253.0 & 35 & 126.0 & 20 & 90.1 & 36 \\
\hline Thiamethoxam & 4.1 & 292.0 & 19 & 211.0 & 13 & 181.0 & 22 \\
\hline Thidiazuron & 5.2 & 221.0 & 25 & 101.9 & 14 & 93.9 & 15 \\
\hline Thiobencarb & 8.4 & 258.2 & 30 & 125.0 & 23 & 89.0 & 46 \\
\hline Thiofanox & 5.4 & 235.9 & 28 & 142.9 & 10 & 42.9 & 32 \\
\hline $\begin{array}{c}\text { Thiophanate- } \\
\text { methyl }\end{array}$ & 5.2 & 343.0 & 25 & 151.0 & 20 & 311.0 & 12 \\
\hline Triadimefon & 6.6 & 294.1 & 35 & 69.3 & 20 & 197.2 & 14 \\
\hline Triadimenol & 6.6 & 296.1 & 12 & 227.1 & 15 & 99.1 & 15 \\
\hline Trichlorfon & 4.2 & 257.0 & 26 & 109.0 & 16 & 79.0 & 26 \\
\hline Tricyclazole & 5.3 & 190.0 & 32 & 163.0 & 20 & 136.0 & 28 \\
\hline Trifloxystrobin & 8.9 & 409.0 & 30 & 186.0 & 20 & 145.0 & 50 \\
\hline Triflumizole & 9.3 & 346.0 & 24 & 277.9 & 10 & 43.1 & 24 \\
\hline Triflumuron & 8.3 & 359.0 & 28 & 156.1 & 33 & 139.1 & 16 \\
\hline Triticonazole & 7.1 & 318.1 & 25 & 70.1 & 25 & 124.9 & 30 \\
\hline Vamidothion & 4.6 & 288.0 & 24 & 146.0 & 11 & 118.0 & 24 \\
\hline Zoxamide & 7.7 & 336.0 & 38 & 187.1 & 20 & 159.0 & 40 \\
\hline
\end{tabular}


Table A3. GC-MS/MS parameters optimized for pesticide residues determination.

\begin{tabular}{|c|c|c|c|c|c|c|c|c|c|c|}
\hline Compound Name & $\begin{array}{l}\text { Retention } \\
\text { Time (min) }\end{array}$ & $\begin{array}{l}\text { Precurso Ion } \\
(\mathrm{m} / \mathrm{z})\end{array}$ & $\begin{array}{l}\text { Productio Ion } \\
(\mathrm{m} / \mathrm{z})\end{array}$ & $\begin{array}{l}\text { Collisio } \\
\text { Energy (V) }\end{array}$ & $\begin{array}{l}\text { Precurso Ion } \\
(\mathrm{m} / \mathrm{z})\end{array}$ & $\begin{array}{l}\text { Productio Ion } \\
(\mathrm{m} / \mathrm{z})\end{array}$ & $\begin{array}{c}\text { Collisio } \\
\text { Energy (V) }\end{array}$ & $\begin{array}{l}\text { Precurso Ion } \\
(\mathrm{m} / \mathrm{z})\end{array}$ & $\begin{array}{l}\text { Productio Ion } \\
\qquad(\mathrm{m} / \mathrm{z})\end{array}$ & $\begin{array}{l}\text { Collision } \\
\text { Energy (V) }\end{array}$ \\
\hline 2,4-DDD & 20.1 & 237.1 & 165.1 & 20 & 235.0 & 165.2 & 20 & & & \\
\hline 2,4-DDE & 18.6 & 248.0 & 176.2 & 30 & 246.1 & 176.2 & 30 & & & \\
\hline $4,4^{\prime}-\mathrm{DDD}$ & 21.6 & 237.0 & 165.1 & 25 & 235.0 & 165.2 & 20 & 235.0 & 199.1 & 15 \\
\hline $4,4^{\prime}-\mathrm{DDE}$ & 19.9 & 318.0 & 248.0 & 20 & 246.0 & 176.1 & 30 & 317.8 & 246.0 & 20 \\
\hline $4,4^{\prime}-\mathrm{DDT}$ & 22.6 & 236.8 & 165.0 & 22 & 165.1 & 164.3 & 15 & 235.0 & 19.5 & 10 \\
\hline Aldrin & 16.4 & 262.9 & 190.9 & 35 & 262.7 & 191.0 & 30 & 262.9 & 193.0 & 30 \\
\hline Atrazine-desethyl & 12.1 & 172.0 & 69.1 & 15 & 172.0 & 94.1 & 15 & 172.0 & 104.1 & 15 \\
\hline Azinphos-ethyl & 27.0 & 160.0 & 77.0 & 16 & 132.0 & 51.0 & 26 & 132.0 & 77.0 & 12 \\
\hline Benfluralin & 11.9 & 292.1 & 160.1 & 20 & 276.1 & 202.1 & 15 & 292.1 & 264.0 & 10 \\
\hline Bifenox & 25.2 & 341.1 & 281.0 & 12 & 172.9 & 137.9 & 16 & 311.0 & 216.0 & 25 \\
\hline Bifenthrin & 23.8 & 181.2 & 165.2 & 25 & 165.1 & 163.6 & 24 & 181.0 & 179.0 & 12 \\
\hline Bromfenvinphos-methyl & 17.9 & 294.9 & 79.1 & 30 & 109.0 & 79.0 & 6 & 294.9 & 109.0 & 16 \\
\hline Bromophos-ethyl & 18.4 & 302.7 & 284.8 & 14 & 96.9 & 65.0 & 16 & 96.9 & 78.9 & 12 \\
\hline Bromophos-methyl & 17.1 & 331.0 & 286.0 & 25 & 328.9 & 313.8 & 14 & 328.9 & 313.9 & 20 \\
\hline Bromopropylate & 24.1 & 340.8 & 185.0 & 14 & 184.9 & 75.5 & 30 & 184.9 & 156.9 & 12 \\
\hline Chlorbufam & 13.2 & 127.0 & 65.0 & 35 & 53.1 & 27.1 & 10 & 127.0 & 100.0 & 15 \\
\hline Chlordene & 14.0 & 66.1 & 39.1 & 20 & 66.1 & 40.1 & 15 & 66.1 & 65.1 & 10 \\
\hline Chlorfenapyr & 20.6 & 248.9 & 112.0 & 24 & 59.1 & 29.1 & 10 & 59.1 & 31.1 & 5 \\
\hline Chlorfenprop-methyl & 11.4 & 196.0 & 165.1 & 10 & 165.0 & 102.0 & 18 & 165.0 & 137.0 & 10 \\
\hline Chlorfenson & 19.7 & 177.0 & 113.1 & 10 & 111.0 & 75.1 & 15 & 175.0 & 111.0 & 10 \\
\hline Chlorfenvinphos & 17.8 & 323.0 & 266.9 & 14 & 266.9 & 159.0 & 16 & 266.9 & 203.0 & 10 \\
\hline Chlorobenzilate & 20.8 & 139.0 & 74.9 & 26 & 111.0 & 75.1 & 14 & 139.0 & 111.0 & 12 \\
\hline Chlorothalonil & 15.6 & 265.8 & 133.0 & 36 & 228.8 & 168.0 & 8 & 265.8 & 170.0 & 24 \\
\hline Chlorpropham & 12.0 & 213.0 & 127.0 & 14 & 171.0 & 127.0 & 8 & 213.0 & 171.0 & 6 \\
\hline Chlorpyrifos-methyl & 15.1 & 285.9 & 93.0 & 20 & 125.0 & 47.0 & 12 & 125.0 & 79.0 & 6 \\
\hline Chlordane cis & 19.1 & 376.6 & 268.0 & 20 & 372.9 & 266.1 & 20 & 374.9 & 265.8 & 20 \\
\hline Chlordane trans & 18.9 & 374.7 & 265.9 & 22 & 271.7 & 236.8 & 12 & 373.0 & 264.1 & 20 \\
\hline Cyanazine & 16.8 & 198.0 & 55.1 & 24 & 198.0 & 91.0 & 10 & 198.0 & 157.0 & 8 \\
\hline Cyanophenphos & 22.3 & 169.0 & 77.1 & 22 & 157.0 & 77.1 & 22 & 169.0 & 141.0 & 8 \\
\hline Cyanophos & 13.8 & 243.0 & 109.0 & 10 & 125.0 & 79.0 & 60 & 125.0 & 96.9 & 6 \\
\hline Cyflutrin beta & 29.0 & 163.0 & 65.1 & 26 & 163.0 & 91.1 & 12 & 163.0 & 127.1 & 6 \\
\hline Cyflutrin gama & 29.1 & 206.0 & 151.1 & 18 & 163.0 & 91.1 & 12 & 163.0 & 127.0 & 6 \\
\hline
\end{tabular}


Table A3. Cont.

\begin{tabular}{|c|c|c|c|c|c|c|c|c|c|c|}
\hline Compound Name & $\begin{array}{l}\text { Retention } \\
\text { Time (min) }\end{array}$ & $\begin{array}{l}\text { Precurso Ion } \\
(\mathrm{m} / \mathrm{z})\end{array}$ & $\begin{array}{l}\text { Productio Ion } \\
\qquad(\mathrm{m} / \mathrm{z})\end{array}$ & $\begin{array}{c}\text { Collisio } \\
\text { Energy (V) }\end{array}$ & $\begin{array}{l}\text { Precurso Ion } \\
(\mathrm{m} / \mathrm{z})\end{array}$ & $\begin{array}{l}\text { Productio Ion } \\
(\mathrm{m} / \mathrm{z})\end{array}$ & $\begin{array}{c}\text { Collisio } \\
\text { Energy (V) }\end{array}$ & $\begin{array}{l}\text { Precurso Ion } \\
(\mathrm{m} / \mathrm{z})\end{array}$ & $\begin{array}{l}\text { Productio Ion } \\
\qquad(\mathrm{m} / \mathrm{z})\end{array}$ & $\begin{array}{l}\text { Collision } \\
\text { Energy (V) }\end{array}$ \\
\hline Cyhalofop butyl & 26.1 & 256.0 & 91.1 & 24 & 256.0 & 120.0 & 10 & 256.0 & 157.8 & 30 \\
\hline Cyhalothrin gamma & 25.9 & 208.1 & 151.8 & 28 & 181.0 & 151.9 & 22 & 208.1 & 180.9 & 8 \\
\hline Cypermethrin ion 1 & 29.3 & 180.9 & 152.1 & 20 & 163.0 & 91.1 & 12 & 163.0 & 127.1 & 6 \\
\hline Cypermethrin ion 2 & 29.5 & 180.9 & 151.9 & 18 & 163.0 & 91.1 & 12 & 163.0 & 127.0 & 6 \\
\hline Cypermethrin ion 3 & 29.6 & 163.0 & 91.0 & 12 & 163.0 & 127.0 & 6 & 163.0 & 152.1 & 12 \\
\hline Cypermethrin ion 4 & 29.7 & 180.9 & 152.2 & 20 & 163.0 & 91.1 & 12 & 163.0 & 127.1 & 6 \\
\hline Demeton S & 12.8 & 170.0 & 114.0 & 8 & 114.0 & 81.0 & 14 & 142.5 & 114.9 & 6 \\
\hline Diallate & 12.4 & 234.1 & 150.0 & 20 & 86.1 & 43.1 & 5 & 234.1 & 192.1 & 10 \\
\hline Diazinon & 13.4 & 179.1 & 121.5 & 26 & 137.1 & 54.1 & 20 & 137.1 & 84.1 & 12 \\
\hline Dichlorvos & 8.4 & 186.9 & 93.0 & 12 & 109.0 & 79.0 & 6 & 185.0 & 93.0 & 12 \\
\hline Diclofop-methyl & 23.0 & 340.0 & 253.0 & 10 & 252.9 & 126.9 & 36 & 253.0 & 162.1 & 15 \\
\hline Dicloran & 13.5 & 205.9 & 147.9 & 20 & 175.9 & 148.0 & 10 & 205.9 & 176.0 & 10 \\
\hline Dicofol & 17.2 & 250.0 & 139.0 & 10 & 111.0 & 75.0 & 15 & 139.0 & 111.0 & 15 \\
\hline Dieldrin & 20.0 & 277.0 & 240.0 & 8 & 262.7 & 193.0 & 39 & 262.9 & 191.0 & 38 \\
\hline Dinitramine & 13.9 & 260.7 & 194.7 & 18 & 215.9 & 196.0 & 8 & 260.7 & 241.0 & 8 \\
\hline Diphenylamine & 11.9 & 167.1 & 139.4 & 26 & 167.1 & 140.1 & 18 & 167.1 & 166.1 & 16 \\
\hline Disulfoton & 13.9 & 185.9 & 96.9 & 16 & 88.0 & 45.0 & 18 & 88.0 & 59.8 & 6 \\
\hline Endosulfan alpha & 19.2 & 240.9 & 170.0 & 20 & 194.7 & 125.0 & 22 & 194.7 & 159.4 & 8 \\
\hline Endosulfan beta & 21.8 & 240.9 & 205.9 & 15 & 158.9 & 123.0 & 12 & 194.7 & 159.0 & 8 \\
\hline Endosulfan sulfate & 23.1 & 271.8 & 237.0 & 10 & 238.9 & 204.0 & 15 & 271.7 & 235.0 & 12 \\
\hline Endrin & 20.8 & 280.0 & 245.0 & 8 & 245.0 & 173.0 & 22 & 262.0 & 192.0 & 30 \\
\hline Endrin Aldehyde & 22.2 & 344.9 & 281.0 & 8 & 173.0 & 138.1 & 16 & 249.8 & 214.9 & 24 \\
\hline EPTC & 9.3 & 189.1 & 43.1 & 16 & 128.1 & 43.1 & 10 & 189.1 & 128.1 & 6 \\
\hline Esfenvalerate & 31.3 & 181.1 & 152.1 & 20 & 125.0 & 89.0 & 22 & 167.0 & 125.0 & 12 \\
\hline Ethalfluralin & 11.8 & 315.9 & 276.1 & 8 & 276.0 & 202.0 & 14 & 276.0 & 248.1 & 8 \\
\hline Ethion & 20.9 & 230.9 & 128.9 & 22 & 153.0 & 97.0 & 10 & 230.9 & 174.9 & 12 \\
\hline Ethoprophos & 11.7 & 200.0 & 158.0 & 6 & 157.9 & 96.9 & 16 & 157.9 & 113.9 & 6 \\
\hline Fenamiphos & 19.2 & 303.1 & 195.2 & 8 & 154.0 & 139.0 & 10 & 216.9 & 202.0 & 12 \\
\hline Fenchlorphos & 15.4 & 287.0 & 272.0 & 20 & 124.9 & 79.0 & 6 & 169.0 & 110.4 & 6 \\
\hline Fenitrothion & 16.0 & 277.0 & 109.0 & 16 & 125.0 & 79.0 & 8 & 277.0 & 260.0 & 6 \\
\hline Fenpropathrin & 24.3 & 181.0 & 126.8 & 28 & 97.1 & 55.1 & 6 & 181.0 & 151.9 & 22 \\
\hline Fensulfothion & 21.1 & 307.9 & 96.9 & 26 & 293.0 & 97.0 & 16 & 293.0 & 125.0 & 10 \\
\hline Fenthion & 16.5 & 278.0 & 109.0 & 18 & 245.3 & 125.0 & 12 & 278.0 & 169.0 & 14 \\
\hline
\end{tabular}


Table A3. Cont.

\begin{tabular}{|c|c|c|c|c|c|c|c|c|c|c|}
\hline Compound Name & $\begin{array}{c}\text { Retention } \\
\text { Time (min) }\end{array}$ & $\begin{array}{l}\text { Precurso Ion } \\
(\mathrm{m} / \mathrm{z})\end{array}$ & $\begin{array}{l}\text { Productio Ion } \\
(\mathrm{m} / \mathrm{z})\end{array}$ & $\begin{array}{c}\text { Collisio } \\
\text { Energy (V) }\end{array}$ & $\begin{array}{l}\text { Precurso Ion } \\
(\mathrm{m} / \mathrm{z})\end{array}$ & $\begin{array}{l}\text { Productio Ion } \\
(\mathrm{m} / \mathrm{z})\end{array}$ & $\begin{array}{c}\text { Collisio } \\
\text { Energy (V) }\end{array}$ & $\begin{array}{c}\text { Precurso Ion } \\
(\mathrm{m} / \mathrm{z})\end{array}$ & $\begin{array}{l}\text { Productio Ion } \\
(\mathrm{m} / \mathrm{z})\end{array}$ & $\begin{array}{l}\text { Collision } \\
\text { Energy (V) }\end{array}$ \\
\hline Fenvalerate & 31.0 & 225.0 & 119.0 & 18 & 125.0 & 89.0 & 22 & 167.0 & 125.0 & 12 \\
\hline Flucythrinate cis & 29.8 & 451.0 & 199.0 & 10 & 157.0 & 107.0 & 15 & 199.0 & 157.0 & 10 \\
\hline Folpet & 18.7 & 262.0 & 130.0 & 15 & 104.0 & 76.0 & 10 & 130.0 & 102.0 & 12 \\
\hline Formothion & 14.8 & 170.0 & 93.0 & 8 & 125.0 & 79.0 & 8 & 126.1 & 93.0 & 6 \\
\hline $\mathrm{HCH}$ alpha & 12.9 & 218.9 & 182.9 & 8 & 216.9 & 180.9 & 8 & 216.9 & 180.9 & 8 \\
\hline $\mathrm{HCH}$ beta & 13.8 & 218.9 & 182.9 & 8 & 109.0 & 49.0 & 25 & 182.9 & 147.0 & 10 \\
\hline HCH gamma (Lindane) & 14.6 & 218.9 & 182.9 & 8 & 180.9 & 145.0 & 10 & 216.9 & 180.9 & 8 \\
\hline Heptachlor & 15.4 & 273.8 & 238.8 & 15 & 100.0 & 65.1 & 10 & 271.8 & 236.9 & 15 \\
\hline Heptachlor epoxide & 17.8 & 354.9 & 264.9 & 10 & 81.1 & 53.1 & 10 & 352.9 & 262.9 & 10 \\
\hline Heptenophos & 11.0 & 215.0 & 200.0 & 8 & 124.0 & 62.9 & 28 & 124.0 & 89.0 & 12 \\
\hline Hexachlorobenzene & 13.1 & 285.8 & 213.9 & 30 & 283.8 & 213.9 & 30 & 283.8 & 248.9 & 20 \\
\hline Isodrin & 17.4 & 194.9 & 159.0 & 20 & 66.1 & 65.1 & 10 & 192.9 & 123.0 & 30 \\
\hline Isofenphos & 17.5 & 213.0 & 121.0 & 14 & 185.0 & 121.0 & 10 & 213.0 & 185.0 & 6 \\
\hline Malaoxon & 14.9 & 127.0 & 99.0 & 6 & 99.0 & 71.0 & 8 & 127.0 & 109.0 & 12 \\
\hline Malathion & 15.9 & 173.1 & 99.0 & 12 & 92.8 & 63.0 & 8 & 125.0 & 79.0 & 8 \\
\hline Methacrifos & 10.3 & 240.0 & 180.0 & 10 & 125.0 & 79.0 & 8 & 180.0 & 93.0 & 10 \\
\hline Methidathion & 18.7 & 302.6 & 284.9 & 14 & 145.0 & 58.0 & 14 & 145.0 & 85.0 & 6 \\
\hline Methoxychlor & 24.4 & 227.1 & 141.1 & 35 & 227.0 & 184.0 & 20 & 227.1 & 169.1 & 25 \\
\hline Mirex & 26.1 & 273.8 & 238.9 & 15 & 236.8 & 142.9 & 20 & 271.8 & 236.9 & 15 \\
\hline Nitrofen & 21.1 & 285.0 & 164.0 & 20 & 202.0 & 139.0 & 21 & 283.0 & 162.1 & 20 \\
\hline Oxychlordane & 17.8 & 388.8 & 262.9 & 15 & 184.9 & 84.9 & 26 & 184.9 & 121.0 & 12 \\
\hline Oxyfluorfen & 20.1 & 300.0 & 167.0 & 25 & 252.0 & 196.1 & 20 & 300.0 & 223.0 & 20 \\
\hline Paraoxon-ethyl & 15.6 & 149.0 & 91.1 & 10 & 109.0 & 81.0 & 10 & 149.0 & 102.0 & 16 \\
\hline Parathion-ethyl & 16.8 & 291.0 & 109.0 & 12 & 109.0 & 81.0 & 10 & 124.9 & 97.0 & 6 \\
\hline Parathion-methyl & 15.4 & 263.0 & 109.0 & 12 & 124.9 & 47.0 & 12 & 124.9 & 79.0 & 6 \\
\hline Pentachloroaniline & 15.0 & 264.8 & 193.9 & 20 & 262.9 & 191.9 & 20 & 264.8 & 229.9 & 10 \\
\hline Pentachlorobenzene & 11.0 & 249.9 & 214.9 & 15 & 247.9 & 142.0 & 40 & 247.9 & 212.9 & 15 \\
\hline Pentanochlor & 16.1 & 143.1 & 106.1 & 25 & 71.1 & 43.1 & 5 & 141.0 & 77.1 & 30 \\
\hline Permethrin cis & 27.4 & 183.1 & 153.0 & 12 & 163.0 & 91.1 & 12 & 183.1 & 168.0 & 12 \\
\hline Permethrin trans & 27.7 & 183.0 & 153.0 & 14 & 183.0 & 165.1 & 10 & 183.0 & 168.1 & 10 \\
\hline Phorate & 12.4 & 260.0 & 75.0 & 8 & 75.0 & 47.0 & 8 & 121.0 & 65.0 & 8 \\
\hline Phosalone & 26.0 & 182.0 & 74.8 & 30 & 121.1 & 65.0 & 10 & 182.0 & 111.0 & 14 \\
\hline Phosphamidon & 14.6 & 264.1 & 127.0 & 12 & 127.0 & 94.9 & 16 & 127.0 & 109.0 & 12 \\
\hline
\end{tabular}


Table A3. Cont.

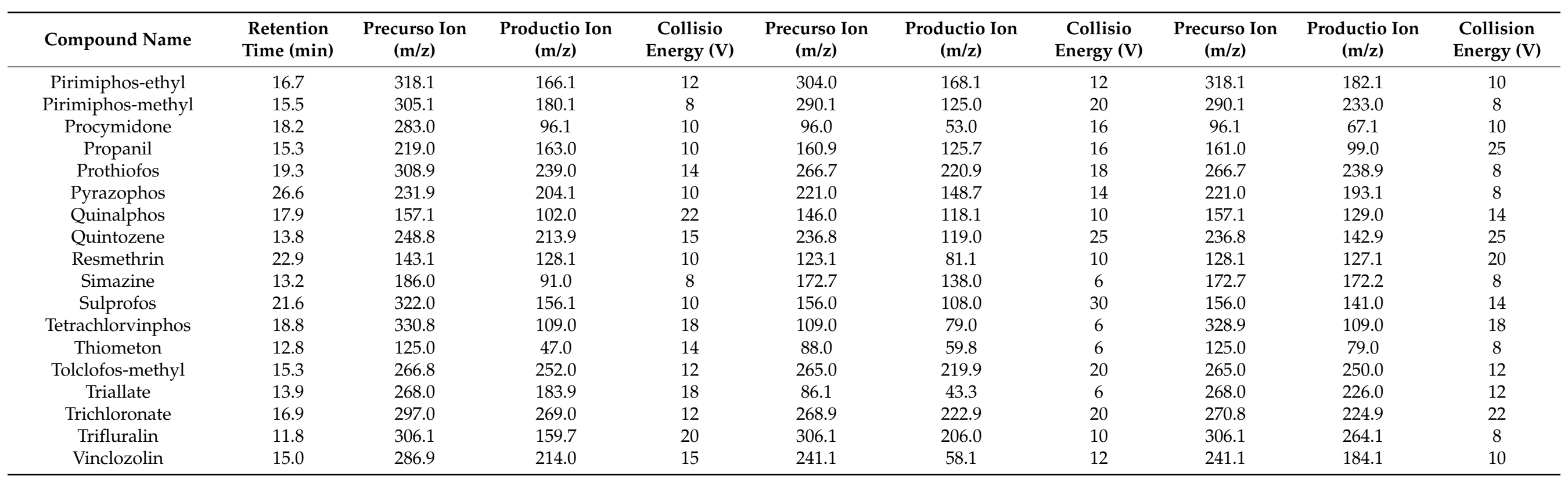




\section{Appendix B}

Table A4. Average recovery, relative standard deviation (RSD), limit of detection (LOD), and limit of quantification (LOQ) in representative cereal (wheat) for mycotoxins.

\begin{tabular}{ccccc}
\hline Compound Name & Average Recovery $\%$ & Repeatability RSD $\%$ & LOD $\boldsymbol{\mu g} / \mathbf{k g}$ & LOQ $\boldsymbol{\mu g} / \mathbf{k g}$ \\
\hline Aflatoxin B1 & 99.1 & 5.4 & 0.30 & 0.15 \\
Aflatoxin B2 & 101.2 & 13.9 & 0.30 & 1.0 \\
Aflatoxin G1 & 104.9 & 7.8 & 0.15 & 0.5 \\
Aflatoxin G2 & 96.9 & 5.8 & 61 & 0.5 \\
Deoxynivalenol & 111.1 & 4.8 & 46 & 200 \\
Fumonisin B1 & 101.4 & 3.6 & 46 & 1.0 \\
Fumonisin B2 & 100.4 & 3.3 & 9 & 30 \\
Zearalenone & 97.2 & 7.0 & 3 & 30 \\
T-2 toxin & 97.3 & 13.8 & 3.4 & 10 \\
HT-2 toxin & 93.5 & 6.0 & 0.30 & 10 \\
Ochratoxin A & 94.3 & & 1.0 \\
\hline
\end{tabular}

Table A5. Average recovery, RSD, LODs, and LOQs in representative cereal (wheat) for found pesticide residues.

\begin{tabular}{ccccc}
\hline Compound Name & Average Recovery $\%$ & Repeatability RSD $\%$ & LOD $\mu$ g/kg & LOQ $\mu$ g/kg \\
\hline Piperonyl butoxide & 89.8 & 14.8 & 0.003 & 0.003 \\
Chlorpyriphos & 70.6 & 6.8 & 0.003 & 0.010 \\
Epoxiconazole & 94.8 & 7.4 & 0.003 & 0.010 \\
Thiofanox & 82.8 & 9.8 & 0.003 & 0.010 \\
Tebuconazole & 93.0 & 9,8 & 0.003 & 0.010 \\
Thiametoxam & 72.8 & 6.5 & 0.003 & 0.010 \\
Carboxin & 83.1 & 19.2 & & 0.010 \\
Cypermethrin I & 80.7 & 11.4 & 0.003 & 0.010 \\
Cypermethrin II & 87.6 & 19.0 & & 0.010 \\
Cypermethrin III & 72.2 & 15.2 & 0.003 & \\
Cypermethrin IV & 82.4 & 5.3 & & 0 \\
Pyrimiphos-methyl & 86.3 & 14.8 & & \\
\hline
\end{tabular}

Table A6. Average recovery, RSD, LODs, and LOQs in representative cereal (wheat) for heavy metals.

\begin{tabular}{ccccc}
\hline Analyte & Average Recovery $\%$ & Repeatability RSD $\%$ & LOD $\boldsymbol{\mu g} / \mathbf{k g}$ & LOQ $\boldsymbol{\mu g} / \mathbf{k g}$ \\
\hline Lead & 103.8 & 1.87 & 0.008 & 0.025 \\
Cadmium & 90.1 & 3.88 & 0.002 & 0.006 \\
Arsenic & 97.8 & 2.77 & 0.0003 & 0.01 \\
Mercury & 98.8 & 4.84 & 0.0003 & 0.001 \\
\hline
\end{tabular}

Table A7. Proficiency testing results for cereals.

\begin{tabular}{cccc}
\hline Proficiency Testing Scheme & Matrix & Analyte & z-Score \\
\hline Romer Labs & \multirow{2}{*}{ Wheat } & Deoxynivalenol & 0.3 \\
\cline { 2 - 3 } CSSMY014-M18161DZ & & Zearalenone & 1.6 \\
\hline & & Aflatoxin B1 & -1.48 \\
Bipea 03-0531 & Aflatoxin B2 & 0 \\
& Barley & Aflatoxin G1 & -0.08 \\
& & Aflatoxin G2 & 0.35 \\
& & T-2 toxin & -0.21 \\
\end{tabular}


Table A7. Cont.

\begin{tabular}{|c|c|c|c|}
\hline Proficiency Testing Scheme & Matrix & Analyte & z-Score \\
\hline \multirow{6}{*}{$\begin{array}{c}\text { Romer Labs } \\
\text { CSSMY017-M19411AF }\end{array}$} & \multirow{6}{*}{ Maize } & Aflatoxin B1 & -1.7 \\
\hline & & Aflatoxin B2 & -1 \\
\hline & & Aflatoxins sum & -1.6 \\
\hline & & Fumonisin B1 & -0.4 \\
\hline & & Fumonisin B2 & -0.4 \\
\hline & & Fumonisin sum & -0.7 \\
\hline \multirow{6}{*}{ Bipea 19b-342 } & \multirow{6}{*}{ Maize } & Azoxystrobin & 1.38 \\
\hline & & Boscalid & 0.4 \\
\hline & & Piperonyl butoxide & 0.36 \\
\hline & & Metalaxyl & 1.85 \\
\hline & & Propiconazole & 0.73 \\
\hline & & Pirimicarb & 0.6 \\
\hline \multirow{17}{*}{ EUPT-CF11 } & \multirow{17}{*}{ Oat flour } & Azoxystrobin & -0.6 \\
\hline & & Carbendazim & 2.1 \\
\hline & & Chlordane trans & 0.3 \\
\hline & & Chlorpyrifos & -0.7 \\
\hline & & Cyhalothrin lambda & -1.8 \\
\hline & & Cyproconazole & -3.8 \\
\hline & & Cyprodinil & -0.8 \\
\hline & & Endosulfan alpha & 0.9 \\
\hline & & Fenbuconazole & 0.7 \\
\hline & & Fenpropimorph & -0.3 \\
\hline & & Fludioxonil & -0.2 \\
\hline & & Flusilazole & 0.7 \\
\hline & & Flutolanil & -1 \\
\hline & & Metconazole & 0.9 \\
\hline & & Prothiofos & 0.0 \\
\hline & & Pyraclostrobin & 0.1 \\
\hline & & Tebuconazole & 0.3 \\
\hline \multirow{2}{*}{ Bipea 32a-90 } & \multirow{2}{*}{ Wheat } & Cadmium & -1.18 \\
\hline & & Lead & -1.07 \\
\hline \multirow{3}{*}{ Fapas 07307} & \multirow{3}{*}{ Rice Cakes } & Arsenic & 0.0 \\
\hline & & Cadmium & 0.0 \\
\hline & & Lead & 1.6 \\
\hline
\end{tabular}

\section{References}

1. Cheli, F.; Battaglia, D.; Gallo, R.; Dell'Orto, V. EU legislation on cereal safety: An update with a focus on mycotoxins. Food Control 2014, 37, 315-325. [CrossRef]

2. Mol, H.G.J.; Plaza-Bolaños, P.; Zomer, P.; De Rijk, T.C.; Stolker, A.A.M.; Mulder, P.P.J. Toward a generic extraction method for simultaneous determination of pesticides, mycotoxins, plant toxins, and veterinary drugs in feed and food matrixes. Anal. Chem. 2008, 80, 9450-9459. [CrossRef] [PubMed]

3. Clarke, R.; Connolly, L.; Frizzell, C.; Elliott, C.T. Challenging conventional risk assessment with respect to human exposure to multiple food contaminants in food: A case study using maize. Toxicol. Lett. 2015, 238, 54-64. [CrossRef] [PubMed]

4. Pose-Juan, E.; Fernández-Cruz, T.; Simal-Gándara, J. State of the art on public risk assessment of combined human exposure to multiple chemical contaminants. Trends Food Sci. Technol. 2016, 55, 11-28. [CrossRef]

5. Dennis, K.K.; Marder, E.; Balshaw, D.M.; Cui, Y.; Lynes, M.A.; Patti, G.J.; Rappaport, S.M.; Shaughnessy, D.T.; Vrijheid, M.; Barr, D.B. Biomonitoring in the era of the exposome. Environ. Health Perspect. 2017, 125, 502-510. [CrossRef]

6. Warth, B.; Spangler, S.; Fang, M.; Johnson, C.H.; Forsberg, E.M.; Granados, A.; Martin, R.L.; Domingo-Almenara, X.; Huan, T.; Rinehart, D.; et al. Exposome-scale investigations guided by global metabolomics, pathway analysis, and cognitive computing. Anal. Chem. 2017, 89, 11505-11513. [CrossRef]

7. Wild, C.P. The exposome: From concept to utility. Int. J. Epidemiol. 2012, 41, 24-32. [CrossRef]

8. Kovač, M.; Šubarić, D.; Bulaić, M.; Kovač, T.; Šarkanj, B. Yesterday masked, today modified; what do mycotoxins bring next? Arch. Ind. Hyg. Toxicol. 2018, 69, 196-214. [CrossRef] 
9. Kovač, T.; Šarkanj, B.; Borišev, I.; Djordjevic, A.; Jović, D.; Lončarić, A.; Babić, J.; Jozinović, A.; Krska, T.; Gangl, J.; et al. Fullerol $\mathrm{C}_{60}(\mathrm{OH})_{24}$ Nanoparticles Affect Secondary Metabolite Profile of Important Foodborne Mycotoxigenic Fungi In Vitro. Toxins 2020, 12, 213. [CrossRef]

10. European Commission. Commission Regulation (EC) No 1881/2006 of 19 December 2006 setting maximum levels for certain contaminants in foodstuffs. Off. J. Eur. Union 2006, 364, 5-24.

11. European Commission. Commission Recomendation of the 27 March 2013 on the presence of T-2 and HT-2 toxin in cereals and cereal products. Off. J. Eur. Union 2013, 91, 12-15. [CrossRef]

12. European Commission. Commission Recommendation of 17 August 2006 on the presence of deoxynivalenol, zearalenone, ochratoxin A, T-2 and HT-2 and fumonisins in products intended for animal feeding. Off. J. Eur. Union 2006, 229, 7-9.

13. European Commission. Directive 2002/32/EC of the European Parliament and of the Council of 7 May 2002 on undesirable substances in animal feed. Luxemb. Off. J. Eur. Communities 2002, 31, 166-177.

14. Pleadin, J.; Sokolović, M.; Perši, N.; Zadravec, M.; Jaki, V.; Vulić, A. Contamination of maize with deoxynivalenol and zearalenone in Croatia. Food Control 2012, 28, 94-98. [CrossRef]

15. Pleadin, J.; Zadravec, M.; Perši, N.; Vulić, A.; Jaki, V.; Mitak, M. Mould and mycotoxin contamination of pig feed in northwest Croatia. Mycotoxin Res. 2012, 28, 157-162. [CrossRef]

16. Pleadin, J.; Vulić, A.; Perši, N.; Škrivanko, M.; Capek, B.; Cvetnić, Ž. Aflatoxin B1 occurrence in maize sampled from Croatian farms and feed factories during 2013. Food Control 2014, 40, 286-291. [CrossRef]

17. Spanic, V.; Marcek, T.; Abicic, I.; Sarkanj, B. Effects of fusarium head blight on wheat grain and malt infected by fusarium culmorum. Toxins 2018, 10, 17. [CrossRef]

18. Spanic, V.; Zdunic, Z.; Drezner, G.; Sarkanj, B. The pressure of fusarium disease and its relation with mycotoxins in the wheat grain and malt. Toxins 2019, 11, 198. [CrossRef]

19. Habschied, K.; Krska, R.; Sulyok, M.; Šarkanj, B.; Krstanović, V.; Lalić, A.; Šimić, G.; Mastanjević, K. Screening of various metabolites in six barley varieties grown under natural climatic conditions (2016-2018). Microorganisms 2019, 7, 532. [CrossRef]

20. Habschied, K.; Šarkanj, B.; Klapec, T.; Krstanović, V. Distribution of zearalenone in malted barley fractions dependent on Fusarium graminearum growing conditions. Food Chem. 2011, 129, 329-332. [CrossRef]

21. Reinholds, I.; Pugajeva, I.; Bavrins, K.; Kuckovska, G.; Bartkevics, V. Mycotoxins, pesticides and toxic metals in commercial spices and herbs. Food Addit. Contam. Part B Surveill. 2017, 10, 5-14. [CrossRef] [PubMed]

22. Cozma, P.; Apostol, L.C.; Hlihor, R.M.; Simion, I.M.; Gavrilescu, M. Overview of human health hazards posed by pesticides in plant products. In Proceedings of the Institute of Electrical and Electronics Engineers IEEE, Sinaia, Romania, $22-24$ June 2017.

23. Choudhary, S.; Raheja, N.; Kumar, S.; Kamboj, M.; Sharma, A. A review: Pesticide residue: Cause of many animal health problems. J. Entomol. Zool. Stud. 2018, 6, 330-333.

24. European Food Safety Authority. The 2016 European Union report on pesticide residues in food. EFSA J. 2018, 16. [CrossRef]

25. Wodaje, A.T. Assessment of some heavy metals concentration in selected cereals collected from local markets of Ambo City, Ethiopia. J. Cereal. Oilseeds 2015, 6, 8-13. [CrossRef]

26. Jaishankar, M.; Tseten, T.; Anbalagan, N.; Mathew, B.B.; Beeregowda, K.N. Toxicity, mechanism and health effects of some heavy metals. Interdiscip. Toxicol. 2014, 7, 60-72. [CrossRef] [PubMed]

27. European Commission. Commission Decision of 14 August 2002 implementing Council Directive 96/23/EC concerning the performance of analytical methods and the interpretation of results. Off. J. Eur. Communities 2002, 21, 8-36.

28. Sulyok, M.; Stadler, D.; Steiner, D. Validation of an LC-MS/MS-based dilute-and-shoot approach for the quantification of $>500$ mycotoxins and other secondary metabolites in food crops: Challenges and solutions. Anal. Bioanal. Chem. 2020, 412, $2607-2620$. [CrossRef]

29. Eskola, M.; Kos, G.; Elliott, C.T.; Hajšlová, J.; Mayar, S.; Krska, R. Worldwide contamination of food-crops with mycotoxins: Validity of the widely cited 'FAO estimate' of 25\%. Crit. Rev. Food Sci. Nutr. 2019, 60, 1-17. [CrossRef]

30. European Commission. Commission Regulation (EC) No 401/2006 of 23 February 2006 laying down the methods of sampling and analysis for the official control of the levels of mycotoxins in foodstuffs. Off. J. Eur. Union 2006, 70, 12-34.

31. Guidance SANTE. Guidance Document on Analytical Quality Control and Method Validation Procedures for Pesticides Residues Analysis in Food and Feed; European Commission SANTE/11813/2017; European Commission: Brussels, Beligum, 2017; pp. 1-46.

32. European Commission. Commission Regulation (EU) 2016/582 of 15 April 2016 amending Regulation (EC) No $333 / 2007$ as regards the analysis of inorganic arsenic, lead and polycyclic aromatic hydrocarbons and certain performance criteria for analysis. Off. J. Eur. Union 2016, 59, 3-6.

33. Pleadin, J.; Staver, M.M.; Markov, K.; Frece, J.; Zadravec, M.; Jaki, V.; Krupić, I.; Vahčić, N. Mycotoxins in organic and conventional cereals and cereal products grown and marketed in Croatia. Mycotoxin Res. 2017, 33, 219-227. [CrossRef] [PubMed]

34. Pleadin, J.; Vulić, A.; Perši, N.; Škrivanko, M.; Capek, B.; Cvetnić, Ž. Annual and regional variations of aflatoxin B1 levels seen in grains and feed coming from Croatian dairy farms over a 5-year period. Food Control 2015, 47, 221-225. [CrossRef]

35. Kovač, T.; Borišev, I.; Kovač, M.; Lončarić, A.; Čačić Kenjerić, F.; Djordjevic, A.; Strelec, I.; Ezekiel, C.N.; Sulyok, M.; Krska, R.; et al. Impact of fullerol $\mathrm{C}_{60}(\mathrm{OH})_{24}$ nanoparticles on the production of emerging toxins by Aspergillus flavus. Sci. Rep. 2020, 10, 1-10. [CrossRef] [PubMed]

36. Marchand, P.A.; Dimier-Vallet, C.; Vidal, R. Biorational substitution of piperonyl butoxide in organic production: Effectiveness of vegetable oils as synergists for pyrethrums. Environ. Sci. Pollut. Res. 2018, 25, 29936-29942. [CrossRef] [PubMed] 
37. Köycü, N.D. Effect on Fusarium Culmorum of Fungicides Used in Wheat Seed. In Proceedings of the International Congress on Engineering And Life Sciences ICELS, Kastamonu, Turkey, 26-19 April 2018; pp. 593-601.

38. Miloš, S.; Jurković, Z.; Raspudić, E.; Lončarić, Z. Risk Assessment of Pesticide Residues in Food on Croatian Market: Should We Worry? J. Hyg. Eng. Des. 2014, 8, 77-81.

39. European Food Safety Authority (EFSA). The 2017 European Union report on pesticide residues in food. EFSA J. $2019,17$. [CrossRef]

40. Medina-Pastor, P.; Triacchini, G. The 2018 european union report on pesticide residues in food. EFSA J. 2020, 18, 1-103. [CrossRef]

41. The Rapid Alert System for Food and Feed (RASFF). 2016 Annual Report; Publications Office of the EU: Luxembourg, 2017; ISBN 978-92-79-68053-6.

42. The Rapid Alert System for Food and Feed (RASFF). 2017 Annual Report; Publications Office of the EU: Luxembourg, 2018; ISBN 978-92-79-80317-8.

43. The Rapid Alert System for Food and Feed (RASFF). 2018 Annual Report; Publications Office of the EU: Luxembourg, 2019; ISBN 978-92-76-02637-2. 